\title{
Inhibitory Circuits in Cortical Layer 5
}

\author{
Alexander Naka ${ }^{1 *}$ and Hillel Adesnik ${ }^{1,2 *}$ \\ ${ }^{1}$ The Helen Wills Neuroscience Institute, University of California Berkeley, Berkeley, CA, USA , ${ }^{2}$ Department of Molecular and \\ Cell Biology, University of California Berkeley, Berkeley, CA, USA
}

Inhibitory neurons play a fundamental role in cortical computation and behavior. Recent technological advances, such as two photon imaging, targeted in vivo recording, and molecular profiling, have improved our understanding of the function and diversity of cortical interneurons, but for technical reasons most work has been directed towards inhibitory neurons in the superficial cortical layers. Here we review current knowledge specifically on layer 5 (L5) inhibitory microcircuits, which play a critical role in controlling cortical output. We focus on recent work from the well-studied rodent barrel cortex, but also draw on evidence from studies in primary visual cortex and other cortical areas. The diversity of both deep inhibitory neurons and their pyramidal cell targets make this a challenging but essential area of study in cortical computation and sensory processing.

Keywords: neocortex, barrel cortex, sensory cortex, layer 5, inhibition, interneuron, inhibitory microcircuits

\section{THE DIVERSITY OF LAYER 5 EXCITATORY NEURONS}

\section{OPEN ACCESS}

Edited by:

Ariel Agmon,

West Virginia University, USA

Reviewed by:

Heiko J. Luhmann,

Mainz University Medical Center,

Germany

Solange P. Brown,

Johns Hopkins University, USA

*Correspondence:

Alexander Naka alex.naka@berkeley.edu;

Hillel Adesnik

hadesnik@berkeley.edu

Received: 19 January 2016 Accepted: 18 April 2016

Published: 06 May 2016

Citation:

Naka $A$ and Adesnik H (2016) Inhibitory Circuits in Cortical Layer 5.

Front. Neural Circuits 10:35. doi: 10.3389/fncir.2016.00035
Before surveying the existent literature on layer 5 (L5) inhibitory neurons, we briefly review current knowledge on the connectivity and physiological properties of L5 pyramidal cells (PCs), as it provides important context for understanding L5 inhibitory circuits. One feature that distinguishes L5 from other cortical layers is the diversity of its PCs, which send a myriad of long-range projections to other cortical and sub-cortical structures (Lévesque et al., 1996; Veinante et al., 2000; Hattox and Nelson, 2007; Aronoff et al., 2010; reviewed in Harris and Shepherd, 2015). This simple anatomical fact establishes L5 as a primary cortical layer involved in the top-down control of other brain areas. Exactly how L5 circuits parse information to influence downstream circuits and control behavior is one of the central questions in neuroscience. Even though L5 is conventionally thought of as primarily an output layer, L5 PCs also receive direct thalamocortical input (Agmon and Connors, 1992; Meyer et al., 2010; Wimmer et al., 2010; Oberlaender et al., 2012; Rah et al., 2013) and can be driven by thalamic activity alone (Constantinople and Bruno, 2013), suggesting that L5 is an important input layer as well. L5 PCs also receive input from all cortical layers and are thus uniquely positioned to integrate nearly every local and afferent pathway in the cortex (Markram et al., 2015). Without exception, signals transmitted via these pathways invoke a mixture of synaptic excitation and inhibition (reviewed in Isaacson and Scanziani, 2011). Thus inhibition onto L5 PCs, the focus of this review, is crucial for nearly every aspect of L5 function.

L5 PCs can be broadly subdivided based on their projection targets into: (1) the pyramidal tract $(\mathrm{PT})$ neurons, which project to subcortical regions, are located mainly in layer $5 \mathrm{~B}$, and display impressive "thick-tufted" apical dendritic morphologies; and (2) intratelencephalic (IT) neurons, which project mainly to other cortical regions and striatum, are found mainly in layer 5A, and have smaller and less complex dendrites (Hattox and Nelson, 2007; Larsen et al., 2008). PT and IT cells interconnect asymmetrically: while IT cells form excitatory synapses onto PT cells as well as other IT cells, PT cells preferentially connect to other PT cells 
(Brown and Hestrin, 2009; Lefort et al., 2009; Perin et al., 2011; Kiritani et al., 2012; Harris and Shepherd, 2015; Figure 1A). The two cell types are also distinguished by their intrinsic properties (Agmon and Connors, 1989, 1992; Chagnac-Amitai et al., 1990; Schubert et al., 2001), plasticity (Jacob et al., 2012; Greenhill et al., 2015), and more (Table 1). Furthermore, both PT and IT neurons can be further sub-divided based on their unique subsets of subcortical or cortical targets (Hattox and Nelson, 2007).

As a whole, L5 PCs have distinct physiological properties in vivo that distinguish them from excitatory neurons in other layers. First, L5 PCs display very broad sensory tuning (Brecht et al., 2003; Manns et al., 2004; de Kock et al., 2007; Sakata and Harris, 2009; Kim et al., 2015; Lur et al., 2016). Second, L5 PCs, especially PT cells, fire at high rates both spontaneously and during sensory responses (de Kock et al., 2007; Sakata and Harris, 2009; O'Connor et al., 2010; Hires et al., 2015). Third, many L5 PCs exhibit reductions in their firing rate during sensory stimulation or behavior, a feature not often seen in other cortical neurons, which might serve to expand their dynamic range (Krupa et al., 2004; Pluta et al., 2015; Sofroniew et al., 2015). These properties suggest that L5 PCs employ a dense coding strategy (reviewed in Harris and Mrsic-Flogel, 2013), which stands in contrast to the sparse code that has been observed in L2/3 (Brecht et al., 2003; Kerr et al., 2007; Crochet et al., 2011; Clancy et al., 2015; Peron et al., 2015) and other layers (de Kock et al., 2007; de Kock and Sakmann, 2009; O'Connor et al., 2010; reviewed in Barth and Poulet, 2012). L5 PCs are highly intrinsically excitable, and can integrate excitatory inputs from many different sources-both of which probably help establish this dense code (Schubert et al., 2001, 2006; Hooks et al., 2011; Zarrinpar and Callaway, 2016; Schnepel et al., 2015). Another major factor is the diverse cast of inhibitory circuits impinging onto L5 PCs.

\section{MAJOR SUBTYPES OF LAYER 5 INHIBITORY NEURONS}

Cortical interneurons can be broadly sub-divided into distinct cell types based on their morphology, connectivity, molecular and developmental identity, and electrophysiological and synaptic properties (Markram et al., 2004; Ascoli et al., 2008; DeFelipe et al., 2013). Increasingly, these cell types are being linked to specific functional specializations (reviewed in Gentet, 2012; Petersen and Crochet, 2013; Kepecs and Fishell, 2014; Petersen, 2014; Roux and Buzsáki, 2015; Womelsdorf et al., 2014). Cortical inhibitory interneurons can be grossly separated into three essentially non-overlapping groups based on their expression of the molecular markers parvalbumin (PV), somatostatin (SOM), or the serotonin receptor 5HT3aR (Rudy et al., 2011). Each molecular group can be subdivided into multiple cell types, though exactly how many remains unclear. The diversity of inhibitory cell types in the neocortex has been reviewed extensively elsewhere (Markram et al., 2004; Ascoli et al., 2008; Rudy et al., 2011; Huang, 2014; Kepecs and Fishell, 2014; Kubota, 2014; Taniguchi, 2014), so we will limit our discussion to the most relevant aspects for inhibitory circuits in L5 (Supplementary Table 1).

\section{PV Neurons}

PV-expressing GABAergic neurons constitute the largest subclass of L5 interneurons (Gonchar et al., 2008; Lee et al., 2010; Xu et al., 2010). All PV cells share a distinctive "fast-spiking" electrophysiological phenotype. In addition to their eponymous fast action potentials (sometimes also called thin or narrow), these neurons also display little or no spike-frequency adaptation, rapid membrane kinetics, and rapid synaptic conductances, which collectively allow them to fire precisely timed spikes at high rates (Hu et al., 2014). Importantly, the fast-spiking phenotype has allowed experimenters to distinguish PV cells from other types of neurons (such as PCs or SOM interneurons, which typically have broader spikes) during extracellular recording in vivo. The vast majority of information we have on L5 interneurons in vivo primarily derives from this type of analysis.

Most PV cells in L5 are basket cells whose axons densely target the perisomatic compartments of PCs, allowing them to impose rapid and powerful inhibition on the surrounding network (Xiang et al., 2002). Anatomically, basket cells take on a range of morphologies that have been described as "large", "small" and "nest" derived from the unique and diverse structure of their intracortical axons (Gupta et al., 2000; Wang et al., 2002), and these different axonal phenotypes may correlate to functional distinctions (Buchanan et al., 2012; Bortone et al., 2014). However the differential circuit connectivity and function of these various basket subtypes remain to be fully elucidated.

Chandelier cells are the second major subtype of PV cells. These neurons have a highly distinctive and characteristic axonal morphology and primarily synapse on PC axons. Yet they are technically challenging to study due to their relative scarcity and current barriers to specific genetic access to them (Taniguchi et al., 2013; Huang, 2014). While chandelier cells are GABAergic, in some conditions they can actually depolarize postsynaptic PCs due to the locally elevated chloride reversal potential in the axon initial segment. However, the questions of whether and when chandelier cells exert excitatory or suppressive effects on their postsynaptic targets remain open (Szabadics et al., 2006; Glickfeld et al., 2009; Woodruff et al., 2010, 2011). Interestingly, while chandelier cells have been observed to occupy the infragranular layers (Inda et al., 2009; Taniguchi et al., 2013), to the best of our knowledge no direct evidence of connections from L5 chandelier cells onto L5 PCs has been published; these may be comparatively rare (Peters et al., 1982). However, connections onto L5 PCs have been observed originating from chandelier cells located in the supragranular layers, where they are more common (Jiang et al., 2013; Lee et al., 2015).

\section{SOM Neurons}

The second largest class of L5 GABAergic neurons are SOM cells. In contrast to PV neurons, SOM cells primarily target the dendrites of excitatory neurons and receive facilitating excitatory input (Reyes et al., 1998; Markram et al., 2004; Silberberg and Markram, 2007). The best-studied type of SOM cell is the Martinotti cell, which is a subclass found across 


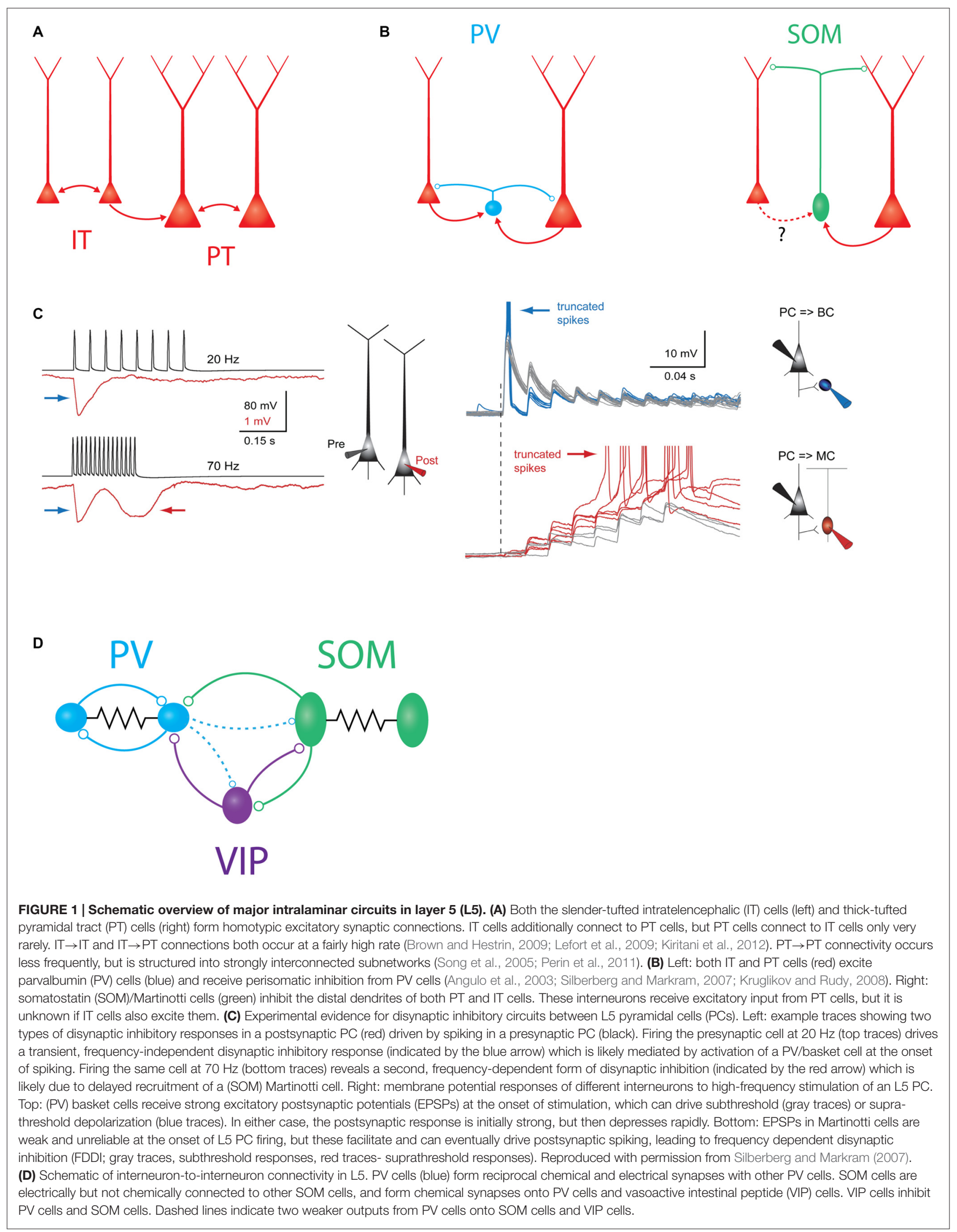


Type

(Other common nomenclatures)
Pyramidal Tract (PT)

(Thick tufted, intrinsic bursting)
Intratelencephalic (IT)

(Slender tufted/short, regular spiking)

\section{Morphology}

Larsen and Callaway (2006); Schubert et al. (2006); Oberlaender et al. (2011); Narayanan et al. (2015); and Ramaswamy and Markram (2015)

\section{Projection targets}

Wise and Jones (1977); Lévesque et al. (1996); Veinante et al. (2000); Hattox and Nelson (2007); and Groh et al. (2010)

\section{Intrinsic properties}

Larkum et al. (1999a,b, 2009); Schubert et al. (2006); Grewe et al. (2010); and Groh et al. (2010)

\section{Local excitatory connectivity}

Markram (1997); Schubert et al. (2001, 2006);

Feldmeyer et al. (2005); Song et al. (2005);

Krieger et al. (2007); Frick et al. (2008); Lefort

et al. (2009); Hooks et al. (2011); Perin et al.

(2011); Kiritani et al. (2012); and Kim et al. (2014)

Long-range inputs

Agmon and Connors (1992); Petreanu et al. (2007, 2009); Wimmer et al. (2010); Oberlaender et al. (2012); Xu et al. (2012); Constantinople and Bruno (2013); and Rah et al. (2013)
Broad, thick-tufted apical dendritic arbor, often with a prominent bifurcation in L4 or L2/3.

Local axonal ramification is sparse and mostly restricted to infragranular layers, but spans multiple columns.

Preferentially occupy L5B

Spinal cord, brainstem, superior colliculus, pontine nucleus, ipsilateral striatum, higher-order thalamus

Can fire bursts or doublets, Prominent dendritic spiking, Non-adapting after burst

Receive excitatory input from PCs in all cortical layers; strong inputs from L3, L5PT Engage in reciprocally connected subnetworks with other PT cells but rarely connect to L5 IT

Strong input from ventral posteriomedial nucleus of thalamus (VPM) Weak input from posteromedial nucleus of thalamus (POm) Primary motor cortex and other cortical areas
Smaller dendritic arbor, with a slender apical tuft or no apical tuft.

Local axonal ramification is dense, spans multiple columns and often ascends to supragranular layers.

Preferentially occupy L5A

Ipsilateral and contralateral striatum, contralateral S1, M1 and other cortical areas

Regular or doublet spiking,

Little dendritic excitability

Adapting somatic spikes

Receive excitatory input from PCs in all cortical layers; strong inputs from L2, L4, L5IT, L6 corticothalamic cells Reciprocally connected to other L5 IT; provide excitation to L5 PT

Weak or no input from VPM

Strong input from POM

Primary motor cortex and other cortical areas layers 2-6, but especially prevalent in L5. The axons of L5 Martinotti cells characteristically ascend to upper cortical layers, particularly to L1, where they ramify and form a dense axonal plexus innervating the distal apical dendrites of L5 PCs. Some Martinotti axons also target L4, and overall Martinotti cells display considerable morphological and molecular heterogeneity (Wang et al., 2004; McGarry et al., 2010). This heterogeneity has been demonstrated in a study comparing two transgenic reporter mouse lines (the "X98" line and the more commonly used "GIN" line), which appear to label distinct sets of Martinotti cells with mostly non-overlapping phenotypes (Ma et al., 2006). Another reporter, the "X94" line, labels a third subset of non-Martinotti SOM cells present in both L5 and L4 which display a quasi-fast-spiking electrophysiological phenotype and target their axons almost exclusively to L4 rather than L1. A distinctive feature of $\mathrm{X} 94$ cells in $\mathrm{L} 5$ is that they receive robust excitatory input from thalamocortical axons, indicating that they may play a key role in feed-forward inhibition from thalamus to cortex (Porter et al., 2001; Tan et al., 2008). On the other hand, Martinotti cells receive little or no thalamocortical input in the mature animal (Cruikshank et al., 2010; Ji et al., 2015), though recent results indicate that they may play a transient role in feedforward inhibition during development (Marques-Smith et al., 2016; Tuncdemir et al., 2016).

\section{HT3aR Neurons}

The last major group of L5 GABAergic neurons express the serotonin receptor, 5HT3aR (Lee et al., 2010; Vucurovic et al.,
2010). Even more so than L5 PV and SOM neurons, this subgroup is highly heterogeneous. While $5 \mathrm{HT} 3 \mathrm{aR}$ neurons represent half of the GABAergic cells in L2/3, they comprise only a small fraction $(\sim 10-25 \%)$ of L5 interneurons (Lee et al., 2010; Xu et al., 2010; Rudy et al., 2011). This group includes interneurons expressing the molecular marker vasoactive intestinal peptide (VIP). These neurons have bipolar or bitufted dendritic morphologies and vertically oriented axonal arborizations (Vucurovic et al., 2010; Prönneke et al., 2015). In L2/3, VIP cells have recently been shown to target other interneurons as a part of dedicated disinhibitory circuits. However, VIP cells in L5 appear morphologically distinct from those in upper layers and comparatively little is known about them (Prönneke et al., 2015). Other 5HT3aR expressing interneurons, such as neurogliaform cells, are known to exist but rarely observed in L5 (Oláh et al., 2009; Jiang et al., 2015). Overall, data on 5HT3aR interneurons in L5 are scarce and much further experimentation is needed.

\section{RECURRENT, INTRALAMINAR INHIBITION WITHIN LAYER 5}

\section{Somatic Inhibition}

PV basket-type interneurons mediate a major component of recurrent inhibition within L5. L5 PCs powerfully excite L5 PV cells (Angulo et al., 2003; Jin et al., 2014; Jiang et al., 2015; Pluta et al., 2015) and likely do so in a highly convergent and nonselective manner (Bock et al., 2011; Hofer et al., 2011; Scholl et al., 2015; all in L2/3 of V1). In turn, L5 PV cells connect onto surrounding L5 PCs at a very high rate, and diverge massively, 
with one recent study estimating that each L5 PV cell inhibits $>1000$ L5 PCs (Packer and Yuste, 2011, Figure 1B). This has led to the proposal that PV cells may provide a blanket of dense, non-specific inhibition to all excitatory cells (Fino et al., 2013). Despite this promiscuous connectivity, some studies suggest that the PV population may preferentially inhibit specific PC subtypes (Ye et al., 2015), though reports in L5 conflict over whether IT or PT cells receive more inhibition (Fariñas and DeFelipe, 1991; Lee et al., 2014; Rock and Apicella, 2015). Unlike Martinotti cells (see below), PV cells generally require multiple, co-occurring excitatory inputs in order to spike. However, they are more numerous than Martinotti cells in L5, and paired recordings suggest that the conductance of a PV to PC synapse in L5 is several fold larger than that of a Martinotti to PC synapse (Xiang et al., 2002; Kruglikov and Rudy, 2008), though this is likely partially confounded by the limited ability of somatic recordings to measure distal conductances (Williams and Mitchell, 2008). Thus, PV basket cells are poised to exert direct control over the spiking output of PCs and are likely the dominant inhibitory force in L5.

PV to PC inhibition is likely to be preferentially important during certain moments of cortical activation by sensory stimuli. Excitatory synapses onto PV cells are powerful, but exhibit prominent synaptic depression, and the outputs of PV cells onto L5 PCs depress substantially during trains of action potentials (Galarreta and Hestrin, 1998; Xiang et al., 2002; Silberberg and Markram, 2007; Figure 1C). Thus, as has been demonstrated in the hippocampus and other cortical circuits, PV neurons are typically recruited extremely reliably upon the first action potential in a PC spike train, but may stop firing shortly thereafter (Pouille and Scanziani, 2001; Gabernet et al., 2005). Due to these temporal dynamics, PV-mediated somatic inhibition may impose a temporal window on synaptic integration in L5 PCs, preventing summation of non-coincident inputs. The net consequence of this would be to precisely time the first few spikes in a sensory-driven PC spike train (Silberberg and Markram, 2007), similar to what has been shown for PV cells in L4 for thalamocortical input (Gabernet et al., 2005). The enforcement of such a precisely timed integration window may contribute to neuronal tuning in the whisker system (Wilent and Contreras, 2005), and enable temporal coding of stimulus features such as texture or object location (Petersen et al., 2002; Jadhav et al., 2009; Pitas et al., 2016). In agreement with this notion, in vivo recordings show that fast-spiking (putatively PV) cells in L5, and especially L5B, encode a high degree of information about the temporal features of a sensory stimulus and may play an important role in initiating precisely timed sequences of spikes during sensory responses (Reyes-Puerta et al., 2015a,b).

\section{Dendritic Inhibition}

While PV neurons chiefly inhibit the soma and proximal dendrites of L5 PCs, SOM cells are thought to primarily target PC dendrites. In fact, one of the best understood recurrent inhibitory circuits within L5 is a motif in which L5 Martinotti cells mediate frequency dependent disynaptic inhibition (FDDI) between L5 PCs. FDDI is generated when an L5 PC fires a high-frequency burst of action potentials and excites a postsynaptic L5 Martinotti cell (Silberberg and Markram, 2007, Figure 1C). Because excitatory synapses onto Martinotti cells undergo strong short term facilitation, high frequency input from only one or a few PCs is sufficient to drive spiking in the Martinotti cell and inhibit the dendrites of nearby PCs (Kapfer et al., 2007; Silberberg, 2008; Berger et al., 2010; Kwan and Dan, 2012). This motif is widespread and occurs in the visual, auditory, motor, and prefrontal cortices in addition to somatosensory cortex (Berger et al., 2009).

The FDDI motif allows a small number of PCs to spread inhibition widely to the surrounding network-as few as four L5 PCs firing at high frequency is enough to drive inhibition in virtually all nearby L5 PCs (Berger et al., 2010). FDDI seems to recruit a relatively small number of L5 Martinotti cells, but these diverge extensively onto the surrounding PC network (Fino and Yuste, 2011; Jiang et al., 2015). FDDImediated connections between PT cells appear to be structured, since FDDI occurs reciprocally between two PT cells much more often than would be expected by chance (Berger et al., 2009). This enhanced reciprocity is reminiscent of motifs found in excitatory connectivity between PCs, and suggests that the indirect connectivity created by FDDI might complement the structured subnetworks that have been observed in cortical microcircuits (Yoshimura et al., 2005; Kampa et al., 2006; Perin et al., 2011). At first glance, this result is difficult to reconcile with the promiscuous, non-selective outputs of SOM cells (Fino and Yuste, 2011); this could potentially be resolved by specificity in excitatory connectivity onto SOM cells (Yoshimura and Callaway, 2005; Otsuka and Kawaguchi, 2009, 2013), or by "soft" structure in the synaptic weights of a densely connected PC-SOM network that shapes how Martinotti cells are recruited.

While FDDI can also occur outside of L5 (Kapfer et al., 2007), FDDI within L5 appears to be specific to PT (thick-tufted) PCs, since it is not observed between pairs of IT cells in L5 (Le Bé et al., 2007). The mechanism of this specificity is unclear, since Martinotti cells seem to target pyramidal cells non-selectively (Fino and Yuste, 2011; Jiang et al., 2015), and both PT and IT cells in prefrontal cortex receive equal amounts of SOM-mediated inhibition (Lee et al., 2014). One possibility is that L5 IT cells are simply less efficacious than PT cells at recruiting Martinotti cells to spike (Figure 1B). Future experiments utilizing paired recordings between identified L5 IT cells and Martinotti cells could resolve this. Another open question is whether PT cells can drive Martinotti-mediated FDDI onto the dendrites of L5 IT cells. If so, this disynaptic motif would represent an interesting inversion of the asymmetric connectivity from IT cells onto PT cells. Emerging evidence suggests that indirect circuits of this sort underlie stereotyped inhibitory interactions between excitatory cell types in cortex (Adesnik and Scanziani, 2010; Olsen et al., 2012; Xue et al., 2014; Yamawaki and Shepherd, 2015); these circuits might be thought of as inhibitory "pathways" in the cortical microcircuit (Naka, 2015) and will be an important topic for future study.

More broadly, FDDI might represent an avenue for PT cells to broadcast inhibition throughout the local microcircuit. While PT cells receive and integrate input widely, they do not locally excite 
many other excitatory neurons, except for other PT cells (Brown and Hestrin, 2009; Lefort et al., 2009; Harris and Shepherd, 2015; Jiang et al., 2015; Yamawaki and Shepherd, 2015). However, by harnessing the massive divergence of Martinotti cells, L5 PT cells can potentially route inhibition to a large cohort of neurons across multiple layers. Burst firing by one or a small number of L5 PT cells might therefore represent a "call to order", quieting activity throughout an entire cortical column by activating FDDI.

FDDI may serve several functional roles during sensory processing. Most simply, it can act as negative feedback, inhibiting PCs in response to sustained epochs of high activity. More subtly, it can alter synaptic integration in L5 PCs by suppressing electrogenic events in the dendrites. The apical dendrites of L5 PCs can couple with the somatic compartment via dendritic calcium and NMDA spikes (Larkum et al., 1999b; Larkum, 2013; Major et al., 2013), which are highly sensitive to dendritic inhibition (Larkum et al., 1999b; Larkum and Zhu, 2002; Marlin and Carter, 2014). By suppressing the initiation of dendritic spikes FDDI could modulate the gain of the input/output function in L5 PCs (Larkum et al., 2004; Murayama et al., 2009), influence temporal correlations between L5 PCs (Berger et al., 2010), and shape tuning (Lavzin et al., 2012; $\mathrm{Xu}$ et al., 2012). In the same vein, since dendritic spikes are thought to be crucial for burst spiking, particularly in PT cells, FDDI can control the firing mode of L5 PCs by reducing burst firing. Lastly, since L5 PC apical tufts in the barrel cortex are major targets of "top-down" axons from higher cortical areas, including from frontal and motor areas (Petreanu et al., 2009, 2012; Mao et al., 2011; Manita et al., 2015), FDDI may act as a gate for feedback input to the primary somatosensory cortex. Since corticocortical feedback axons convey contextual and behavior related information to S1, FDDI is in a position to powerfully influence how context and brain state influence sensory processing (Larkum, 2013).

In addition to directly hyperpolarizing or shunting their postsynaptic targets via ionotropic $\mathrm{GABA}_{a}$ receptors, a recent study has shown that SOM cells in L2/3 can also reduce the probability of release at pyramidal-to-pyramidal synapses via a form of $\mathrm{GABA}_{b}$ mediated presynaptic inhibition (Urban-Ciecko et al., 2015). It is not yet known if this phenomenon affects excitatory transmission onto L5 PCs, nor if L5 SOM cells also engage in this form of inhibition.

\section{Inhibition onto Other Interneurons in L5}

L5 interneurons also form circuits with other interneurons. L5 PV cells form both electrical and chemical synapses with other PV cells at a high rate (Galarreta and Hestrin, 1999, 2002). These densely coupled PV networks have been implicated in driving network synchrony and generating oscillations (Hestrin and Galarreta, 2005). In contrast, SOM cells generally seem to inhibit each other rarely or not at all, but do inhibit PV cells (Ma et al., 2012; Pfeffer et al., 2013; Zhang et al., 2014; Jiang et al., 2015; Tuncdemir et al., 2016). This asymmetric connectivity pattern among interneurons suggests that L5 SOM cell activity might redistribute inhibition along the somato-dendritic axis of L5 PCs, driving dendritic inhibition while simultaneously disinhibiting the somatic compartment by suppressing PV cells. SOM cells also inhibit other interneurons, including VIP cells (Pfeffer et al., 2013; Chen et al., 2015; Jiang et al., 2015).

In L2/3, VIP cells have emerged as specialists for disinhibition, which can release PC networks from inhibition by selectively suppressing other interneurons, especially SOM cells (Lee et al., 2013; Pfeffer et al., 2013; Pi et al., 2013; Fu et al., 2014; Karnani et al., 2016a,b). This effect has not yet been investigated in deeper layers, but seems likely to occur in some form. In L5, both PV and SOM cells are innervated by VIP inhibitory synapses (Dávid et al., 2007; Pfeffer et al., 2013). In the case of PV cells, VIP boutons preferentially target the soma, suggesting that VIP-mediated inhibition likely has a powerful influence over PV spiking in the same manner that PV neurons themselves yield control over PC spiking (Hioki et al., 2013). While VIP neurons are comparatively scarce in L5, the axons of L2/3 VIP neurons descend into deeper layers and connect to L5 PCs and interneurons (Jiang et al., 2013; Walker, 2016).

The set of interneuron-to-interneuron connectivity motifs described above has recently emerged as a "canonical" motif in cortical microcircuits (Figure 1D). However, other circuits outside of this scheme are also known to exist. Within L4 of the barrel cortex, PV cells provide dense reciprocal inhibition back onto SOM cells. Studies in V1 indicate that PV to SOM connectivity is much weaker in L5 (Pfeffer et al., 2013; Jiang et al., 2015), but it may still be fairly strong in L5 of the barrel cortex (Walker, 2016). Furthermore, PV cells also inhibit VIP cells to some extent in barrel cortex and V1 (Staiger et al., 1997, 2002; Pfeffer et al., 2013; Karnani et al., 2016b). Thus connectivity between these classes of interneurons is actually all-to-all, albeit with some connections being much stronger than others.

\section{FEED-FORWARD, TRANSLAMINAR INHIBITION OF L5}

In addition to intralaminar circuits, L5 is subject to a number of inhibitory influences from other cortical layers in the local circuit. Translaminar inhibition of L5 can derive either from input from GABAergic cells in other cortical layers that target L5 PCs, or from the synaptic activation of GABAergic cells within L5 through translaminar excitatory afferents. With respect to the former scenario, studies using axonal reconstruction, paired intracellular recordings, and viral tracing methods indicate that L5 PCs receive input from a substantial number of interneurons in L2/3, L4, and L6, albeit at a lower frequency than from L5 interneurons (Helmstaedter et al., 2009a,b,c; Jiang et al., 2013; Lee et al., 2015; DeNardo et al., 2015; Figure 2A). Connections from several different varieties of interneurons in layers 1 and 2/3 have been observed onto L5 PCs (Jiang et al., 2013, 2015). Interestingly, different L2/3 interneurons appear to target specific dendritic domains of L5 PCs (Jiang et al., 2013), a result which has been mirrored by recent work in the hippocampus (Bloss et al., 2016). Since dendritic inhibition can be quite spatially precise (Chiu et al., 2013; Marlin and Carter, 2014; Müllner et al., 2015), this organization might allow for celltype specific control over the distinct spatial domains of the various types of dendritic spiking that occur in L5 PCs 

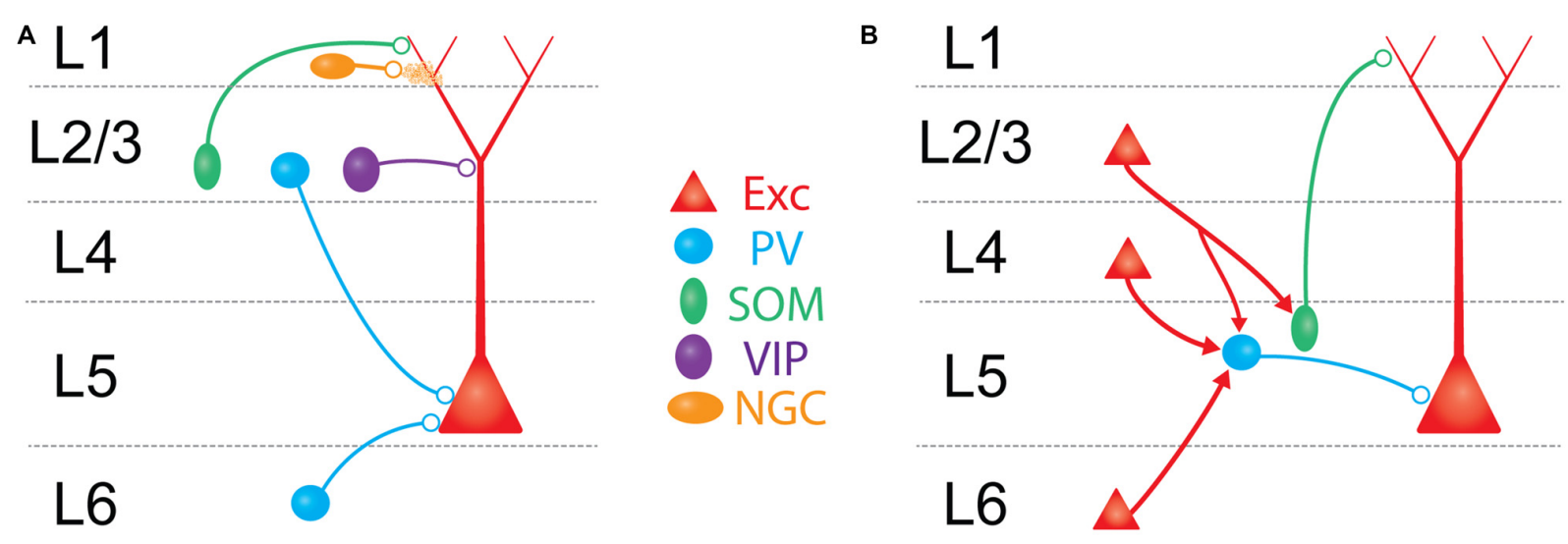

FIGURE 2 | Schematic overview of major translaminar inhibitory circuits impinging on L5 PCs. (A) Inhibition arises from multiple types of interneurons outside of L5. In L1, 5HT3aR/Neurogliaform cells (NGCs, mustard) inhibit L5 PCs via volume release of GABA. In L2/3, SOM/Martinotti cells (green) and VIP cells (purple) target the apical dendrites of L5 PCs, while PV/basket cells (blue) synapse onto the perisomatic compartment via descending axons. In L6, translaminar PV/basket cells inhibit L5 PCs via ascending axons. (B) Excitatory translaminar pathways recruit L5 interneurons. Excitatory cells in L2/3, L4, and L6 can target PV/basket cells. Additionally, L2/3 PCs synapse onto L5 SOM/Martinotti cells.

(Larkum et al., 2009). Studies in mouse V1 have described a translaminar inhibitory circuit in which a subclass of L6 PV neurons can powerfully suppress PCs across all other cortical layers, including L5 (Olsen et al., 2012; Bortone et al., 2014). If this circuit also exists in the barrel cortex, it could play a major role in L5 gain control during sensory activity.

Despite the existence of these direct translaminar inhibitory pathways, optogenetic experiments mapping inhibitory inputs to L5 PCs (either from GABAergic non-specifically, or selectively from PV neurons) suggest that inhibition onto L5 PCs most strongly originates from interneurons within L5 (Schubert et al., 2001, 2006; Brill and Huguenard, 2010; Kätzel et al., 2011; Pluta et al., 2015). Thus the major source of translaminar inhibition to L5 PCs is more likely to be through the synaptic recruitment of L5 interneurons by afferent axons from other cortical layers (Figure 2B).

With the exception of L1, all cortical layers make excitatory axonal projections onto L5, which can recruit L5 interneurons to fire. This recruitment, often termed "feed-forward inhibition" (FFI), is a nearly ubiquitous motif in cortical microcircuits where afferent excitatory input simultaneously recruits local inhibitory neurons that provide inhibition to the same cells receiving excitation. Circuits for FFI have been well studied at the projections from thalamus to L4 (Gibson et al., 1999; Bruno and Simons, 2002; Swadlow, 2003; Gabernet et al., 2005; Wilent and Contreras, 2005; Sun et al., 2006; Cruikshank et al., 2007, 2010; Daw et al., 2007), and from L4 to L2/3 (Helmstaedter et al., 2008; Xu and Callaway, 2009; House et al., 2011; Adesnik et al., 2012; Elstrott et al., 2014; Li et al., 2014; Xue et al., 2014). In these pathways, incoming axons primarily recruit PV interneurons in the recipient layer. PV-mediated FFI serves many functions: it enhances the temporal specificity of incoming signals (Pouille and Scanziani, 2001; Gabernet et al., 2005), extends the dynamic range of the downstream population response (Pouille et al., 2009), and imposes a synchrony filter on incoming inputs (Bruno, 2011). FFI is surprisingly poorly understood in L5. We recently described a translaminar inhibitory circuit in which descending excitatory axons from L4 synapses on L5 PV neurons, which in turn drives inhibition in L5 PCs (Pluta et al., 2015). FFI mediated through this circuit has the net effect of suppressing L5 PCs, sharpening their spatial tuning to tactile stimuli. Although it remains unexplored, we hypothesize that the L4-L5 translaminar inhibitory circuit may also be crucial for the precise timing of touch-evoked spiking in L5 PCs. Another recent study found that L6 PCs can drive disynaptic inhibition onto L5 PCs, specifically to PCs in L5a (likely IT-type PCs, Kim et al., 2014). Interestingly, both of these studies found that afferent input to L5 was much more effective at driving PV neurons than Martinotti cells. Thus inhibition in the L4 $\rightarrow$ L5 and L6 $\rightarrow$ L5 pathways appears to be organized similarly to other translaminar circuits by operating through PV neurons.

Notably, there is a gap in our understanding of FFI in the L2/3 to L5 pathway, one of the densest projections in the cortical microcircuit. Stimulation of L2/3 generates robust FFI in L5 PCs (Pouille et al., 2009; Adesnik and Scanziani, 2010), but preliminary evidence suggests that the mechanisms of $\mathrm{L} 2 / 3 \rightarrow \mathrm{L} 5$ FFI may be unique. Surveys of connectivity onto L5 PV cells in S1 (Jin et al., 2014; Pluta et al., 2015), V1 (Jiang et al., 2015), and other cortical areas (Otsuka and Kawaguchi, 2009; Apicella et al., 2012) expose only moderate excitatory input from L2/3. In contrast, L5 Martinotti cells appear to receive strong input from L2/3 (Kapfer et al., 2007; Otsuka and Kawaguchi, 2009; Apicella et al., 2012; Jiang et al., 2015). This suggests that L2/3 $\rightarrow$ L5 FFI may operate primarily through SOM, rather than PV neurons, and thus predominantly routes inhibition to the L5 PC dendrites, similar to what occurs between the olfactory bulb and the piriform cortex (Stokes and Isaacson, 2010). Because of the filtering cable properties of the apical dendrites, dendritic FFI is likely suboptimal for enforcing rigid temporal control over the somatic spiking of L5 PCs per se, but is instead poised to directly regulate the integration of excitatory inputs from L2/3 PCs to the apical compartment of an L5 PC. 


\section{INTERAREAL RECRUITMENT OF L5 INHIBITION}

Long-range axons from the thalamus, motor cortex, and contralateral S1 that innervate L5 PCs, also recruit L5 inhibitory neurons. For example, ascending axons from primary thalamus ventral posteromedial nucleus, (VPM) can recruit both L5 PV and SOM cells driving various forms of FFI. Interestingly, as described for FFI circuits in hippocampal CA1 (Pouille and Scanziani, 2004), during sustained activity, VPM afferents will initially recruit L5 PV cells, but then switch to driving a subpopulation of L5 non-Martinotti SOM cells labeled by the X94 line (Tan et al., 2008), although it is still unclear if these L5 $\times 94$ neurons project inhibition onto L5 PCs. In contrast, L5 Martinotti cells are not driven by VPM afferents and thus do not appear to participate in thalamocortical FFI (Cruikshank et al., 2010; Ji et al., 2015). Motor cortex afferents to S1 appear to target L5 PV neurons and not L5 Martinotti cells (Kinnischtzke et al., 2014), whereas inputs from contralateral cortex drive inhibition in L5 PCs through at least two distinct circuits. First, callosal projections likely drive FFI using the familiar motif of activating L5 PV neurons, though this has not yet been directly demonstrated in barrel cortex (Karayannis et al., 2006; Lee et al., 2014; Rock and Apicella, 2015). However, these projections also drive an unusual form of slow, $\mathrm{GABA}_{\mathrm{B}}$-dependent inhibition onto the dendrites of L5 PCs, which is mediated by the recruitment of neurogliaform cells in layer 1 (Palmer et al., 2012, 2013). Because callosal projections can synapse onto both the basal and apical compartments of L5 PCs, these dual pathways may allow FFI to be spatially matched to the same subcellular compartments as feed-forward excitation. As many other long-range inputs also form synapses at the distal apical tufts of L5 PCs (Cauller and Connors, 1994; Cauller et al., 1998; Larkum and Zhu, 2002; Petreanu et al., 2009, 2012; Mao et al., 2011; Xu et al., 2012; Manita et al., 2015), it will be interesting to see if these circuits also possess similar capabilities to generate dendritic inhibition.

How might inhibition contribute to communication in these long-range circuits? Long-range afferents to S1 can convey a variety of information, including data on whisker kinematics (Curtis and Kleinfeld, 2009; Petreanu et al., 2012), attentional focus (Harris, 2013; Zagha et al., 2013), and cognitive features in decision-based tasks (Yang et al., 2016). FFI in these circuits will powerfully influence how activity in these afferent pathways is integrated with ongoing local cortical activity. Do these circuits incorporate all L5 PCs in the same manner? PT and IT cells both send and receive long-range inputs in a celltype specific manner. For example, since the axons of PT cells do not cross the corpus callosum, only L5 IT cells will be able to directly activate the circuits for interhemispheric inhibition mentioned above. Furthermore, while both PT and IT cells receive long-range callosal input, two recent studies found that optogenetic activation of callosal fibers generates inhibition in a manner specific to cell-type. Interestingly, this effect appears to be regionally specialized. In auditory cortex
IT neurons are more strongly inhibited, while in prefrontal cortex PT neurons are more strongly inhibited (Lee et al., 2014; Rock and Apicella, 2015). This type of specialization is intriguing, since it might provide a means to direct and gate the flow of activity between different regions of the cortex. More research is needed to determine if similar specificity is seen in other cortical areas or other types of long-range circuits.

\section{FUTURE DIRECTIONS}

Many recent advances in the understanding of cortical inhibitory circuits can be attributed to the widespread adoption of cell-type specific Cre recombinase driver lines (Taniguchi et al., 2011). These lines have allowed investigators to target subsets of cortical interneurons with optical reporters for targeted electrophysiological recording or functional imaging. Experiments using these lines in vivo have revealed how the various interneuron subtypes modulate their responses to different sensory stimuli (Kerlin et al., 2010; Ma et al., 2010; Runyan et al., 2010; Bock et al., 2011; Hofer et al., 2011; Adesnik et al., 2012; Gentet et al., 2012; Scholl et al., 2015) and shifting behavioral states (Lee et al., 2013; Pi et al., 2013; Polack et al., 2013; Fu et al., 2014; Reimer et al., 2014). By expressing optogenetic actuators rather than reporters in these inhibitory cell types, many groups have begun to manipulate interneurons with cell-type specificity to assess their specific contributions to cortical computation and behavior (Adesnik et al., 2012; Atallah et al., 2012; Lee et al., 2012; Wilson et al., 2012; Seybold et al., 2015).

Nevertheless, the recent and widespread reliance on just a few Cre lines (particularly the PV- SOM- and VIP-Cre lines) can also lead to unintended problems. First, these lines are not completely non-overlapping. Up to $\sim 10 \%$ of Cre expressing cells in the widely used SOM-IRES-Cre line may actually be PV expressing, fast-spiking interneurons (Hu et al., 2013). Second, the availability of only a few Cre driver lines for interneurons, along with the paucity of more specific alternatives, has ushered in a new era of "lumping" in the study of interneurons. While this reunification is conceptually beneficial in many ways, it is undoubtedly an over simplification; each of these major subtypes (PV, SOM and 5HT3aR) are highly heterogeneous groups, as described above; for example, the PV-Cre line labels both basket and chandelier cells, while the SOM-Cre line labels both Martinotti and X94 neurons. Third, and perhaps most problematically, all of these Cre lines label interneurons nonspecifically across all cortical layers. This is particularly an issue for in vivo optogenetic manipulations where one-photon illumination will non-specifically activate or suppress Creexpressing interneurons across all cortical layers. This makes it difficult to ascribe results gained with these manipulations to interneurons in specific lamina.

However, there are potential solutions to these problems. The first would be the development and adoption of new transgenic lines that target highly specific inhibitory cell types 
(Taniguchi et al., 2011; Shima et al., 2016). In the short term, further characterizing existing Cre-driver lines that might fractionate the three major interneuron subgroups, such as the Chrna2-Cre line for SOM cells (Leão et al., 2012), or retrofitting existing highly specific GFP lines for Cre expression (Tang et al., 2015), could be extremely valuable. In the long term, advances in single cell transcriptional profiling of cortical neurons could provide quantitative genetic data which may aid in the much more complete delineation of new GABAergic cell types (Armañanzas and Ascoli, 2015; Zeisel et al., 2015; Tasic et al., 2016). At the same time, these data will hopefully identify highly differentially expressed genes between the various subtypes that will provide genetic handles to develop transgenic lines (including Cre reporters) that will permit targeting and optogenetic control of many more subclasses of interneurons. While doing so may depend on sophisticated intersectional strategies involving multiple recombinases, such technology already exists (Fenno et al., 2014; Madisen et al., 2015; reviewed in Huang, 2014).

As we alluded to above, the recent explosion of functional information on inhibitory subtypes in vivo has mostly focused on superficial interneurons due to the technical difficulty of imaging deeper cells in the cortex due to light scattering, and the practical challenges of maneuvering recording pipettes into deeper layers under visual guidance. A number of recent technical advantages should overcome these challenges. These include adaptive optics for deeper in vivo imaging (Wang et al., 2015), implantable optics such as prisms (Andermann et al., 2013) or GRIN lenses (Barretto et al., 2009), three photon imaging (Horton et al., 2013), regenerative amplification of ultrafast pulses (Mittmann et al., 2011), and red-shifted fluorophores that are much less affected by optical scattering in brain tissue. Recent advances in red-shifted calcium and voltage dyes hold particular promise (Inoue et al., 2014; Gong et al., 2015; Huang et al., 2015).

New optical methods will also open new avenues for manipulation of interneuron activity. Novel techniques for spatial light modulation are poised to provide unprecedented

\section{REFERENCES}

Adesnik, H., Bruns, W., Taniguchi, H., Huang, Z. J., and Scanziani, M. (2012). A neural circuit for spatial summation in visual cortex. Nature 490, 226-231. doi: $10.1038 /$ nature 11526

Adesnik, H., and Scanziani, M. (2010). Lateral competition for cortical space by layer-specific horizontal circuits. Nature 464, 1155-1160. doi: 10 . 1038/nature08935

Agmon, A., and Connors, B. W. (1989). Repetitive burst-firing neurons in the deep layers of mouse somatosensory cortex. Neurosci. Lett. 99, 137-141. doi: 10. 1016/0304-3940(89)90278-4

Agmon, A., and Connors, B. W. (1992). Correlation between intrinsic firing patterns and thalamocortical synaptic responses of neurons in mouse barrel cortex. J. Neurosci. 12, 319-329.

Andermann, M. L., Gilfoy, N. B., Goldey, G. J., Sachdev, R. N. S., Wölfel, M., McCormick, D. A., et al. (2013). Chronic cellular imaging of entire cortical columns in awake mice using microprisms. Neuron 80, 900-913. doi: 10.1016/j. neuron.2013.07.052 optogenetic precision, enabling experimenters to arbitrarily target manipulations to single cells or even specific ensembles of neurons (Bovetti and Fellin, 2015). Furthermore, these manipulations are flexible and can be altered online, opening the door to new methods for adaptive/closed-loop experiments to probe network dynamics and structure (Grosenick et al., 2015). However, even in the best of circumstances it is not straightforward to interpret optogenetic perturbations of neurons embedded in recurrent networks (Kumar et al., 2013; Seybold et al., 2015). To account for this, it will be necessary to embrace more complicated, nonlinear models of cortical dynamics and to incorporate these into experimental design (Rubin et al., 2015; Litwin-Kumar et al., 2016). By combining these new technologies with much more specific and sophisticated genetic tools, it should be possible to make considerable progress in understanding the function and impact of L5 interneurons in the coming few years.

\section{AUTHOR CONTRIBUTIONS}

$\mathrm{AN}$ and HA researched, wrote, and edited the manuscript.

\section{ACKNOWLEDGMENTS}

HA is a New York Stem Cell Foundation Robertson Investigator. AN is supported by the National Institute of Neurological Disorders and Stroke of the National Institutes of Health under Ruth L. Kirschstein National Research Service Award F31NS093925. This work was supported by National Institute of Neurological Disorders and Stroke grant DP2NS087725-01 and National Eye Institute grant R01EY023756-01. We thank Jenny Brown, Evan Lyall, Alan Mardinly, Ian Oldenburg, Ming-Chi Tsai, and Julia Veit for helpful comments and feedback.

\section{SUPPLEMENTARY MATERIAL}

The Supplementary Material for this article can be found online at: http://journal.frontiersin.org/article/10.3389/fncir.2016.000 35/abstract

Angulo, M. C., Staiger, J. F., Rossier, J., and Audinat, E. (2003). Distinct local circuits between neocortical pyramidal cells and fast-spiking interneurons in young adult rats. J. Neurophysiol. 89, 943-953. doi: 10.1152/jn.00750.2002

Apicella, A. J., Wickersham, I. R., Seung, H. S., and Shepherd, G. M. G. (2012). Laminarly orthogonal excitation of fast-spiking and low-threshold-spiking interneurons in mouse motor cortex. J. Neurosci. 32, 7021-7033. doi: 10. 1523/JNEUROSCI.0011-12.2012

Armañanzas, R., and Ascoli, G. A. (2015). Towards the automatic classification of neurons. Trends Neurosci. 38, 307-318. doi: 10.1016/j.tins.2015. 02.004

Aronoff, R., Matyas, F., Mateo, C., Ciron, C., Schneider, B., and Petersen, C. C. H. (2010). Long-range connectivity of mouse primary somatosensory barrel cortex. Eur. J. Neurosci. 31, 2221-2233. doi: 10.1111/j.1460-9568.2010. 07264.x

Ascoli, G. A., Alonso-Nanclares, L., Anderson, S. A., Barrionuevo, G., BenavidesPiccione, R., Burkhalter, A., et al. (2008). Petilla terminology: nomenclature of features of GABAergic interneurons of the cerebral cortex. Nat. Rev. Neurosci. 9, 557-568. doi: 10.1038/nrn2402 
Atallah, B. V., Bruns, W., Carandini, M., and Scanziani, M. (2012). Parvalbumin-expressing interneurons linearly transform cortical responses to visual stimuli. Neuron 73, 159-170. doi: 10.1016/j.neuron.2011. 12.013

Barretto, R. P. J., Messerschmidt, B., and Schnitzer, M. J. (2009). In vivo fluorescence imaging with high-resolution microlenses. Nat. Methods 6, 511-512. doi: 10.1038/nmeth.1339

Barth, A. L., and Poulet, J. F. A. (2012). Experimental evidence for sparse firing in the neocortex. Trends Neurosci. 35, 345-355. doi: 10.1016/j.tins.2012. 03.008

Berger, T. K., Perin, R., Silberberg, G., and Markram, H. (2009). Frequencydependent disynaptic inhibition in the pyramidal network: a ubiquitous pathway in the developing rat neocortex. J. Physiol. 587, 5411-5425. doi: 10. 1113/jphysiol.2009.176552

Berger, T. K., Silberberg, G., Perin, R., and Markram, H. (2010). Brief bursts selfinhibit and correlate the pyramidal network. PLoS Biol. 8:e1000473. doi: 10. 1371/journal.pbio. 1000473

Blazquez-Llorca, L., Woodruff, A., Inan, M., Anderson, S. A., Yuste, R., DeFelipe, J., et al. (2014). Spatial distribution of neurons innervated by chandelier cells. Brain Struct. Funct. 220, 2817-2834. doi: 10.1007/s00429-0140828-3

Bloss, E. B., Cembrowski, M. S., Karsh, B., Colonell, J., Fetter, R. D., and Spruston, N. (2016). Structured dendritic inhibition supports branch-selective integration in CA1 pyramidal cells. Neuron 89, 1016-1030. doi: 10.1016/j. neuron.2016.01.029

Bock, D. D., Lee, W.-C. A., Kerlin, A. M., Andermann, M. L., Hood, G., Wetzel, A. W., et al. (2011). Network anatomy and in vivo physiology of visual cortical neurons. Nature 471, 177-182. doi: 10.1038/nature 09802

Bortone, D. S., Olsen, S. R., and Scanziani, M. (2014). Translaminar inhibitory cells recruited by layer 6 corticothalamic neurons suppress visual cortex. Neuron 82 , 474-485. doi: 10.1016/j.neuron.2014.02.021

Bovetti, S., and Fellin, T. (2015). Optical dissection of brain circuits with patterned illumination through the phase modulation of light. J. Neurosci. Methods 241, 66-77. doi: 10.1016/j.jneumeth.2014.12.002

Brecht, M., Roth, A., and Sakmann, B. (2003). Dynamic receptive fields of reconstructed pyramidal cells in layers 3 and 2 of rat somatosensory barrel cortex. J. Physiol. 553, 243-265. doi: 10.1113/jphysiol.2003. 044222

Brill, J., and Huguenard, J. R. (2010). Enhanced infragranular and supragranular synaptic input onto layer 5 pyramidal neurons in a rat model of cortical dysplasia. Cereb. Cortex 20, 2926-2938. doi: 10.1093/cercor/ bhq040

Brown, S. P., and Hestrin, S. (2009). Intracortical circuits of pyramidal neurons reflect their long-range axonal targets. Nature 457, 1133-1136. doi: 10. 1038/nature07658

Bruno, R. M. (2011). Synchrony in sensation. Curr. Opin. Neurobiol. 21, 701-708. doi: $10.1016 /$ j.conb.2011.06.003

Bruno, R. M., and Simons, D. J. (2002). Feedforward mechanisms of excitatory and inhibitory cortical receptive fields. J. Neurosci. 22, 10966-10975.

Buchanan, K. A., Blackman, A. V., Moreau, A. W., Elgar, D., Costa, R. P., Lalanne, T., et al. (2012). Target-specific expression of presynaptic NMDA receptors in neocortical microcircuits. Neuron 75, 451-466. doi: 10.1016/j. neuron.2012.06.017

Cauller, L. J., Clancy, B., and Connors, B. W. (1998). Backward cortical projections to primary somatosensory cortex in rats extend long horizontal axons in layer I. J. Comp. Neurol. 390, 297-310. doi: 10.1002/(sici)10969861(19980112)390:2<297::aid-cne11>3.0.co;2-v

Cauller, L. J., and Connors, B. W. (1994). Synaptic physiology of horizontal afferents to layer I in slices of rat SI neocortex. J. Neurosci. 14, 751-762.

Chagnac-Amitai, Y., Luhmann, H. J., and Prince, D. A. (1990). Burst generating and regular spiking layer 5 pyramidal neurons of rat neocortex have different morphological features. J. Comp. Neurol. 296, 598-613. doi: 10.1002/cne. 902960407

Chen, N., Sugihara, H., and Sur, M. (2015). An acetylcholine-activated microcircuit drives temporal dynamics of cortical activity. Nat. Neurosci. 18, 892-902. doi: 10.1038/nn.4002
Chiu, C. Q., Lur, G., Morse, T. M., Carnevale, N. T., Ellis-Davies, G. C. R., and Higley, M. J. (2013). Compartmentalization of GABAergic inhibition by dendritic spines. Science 340, 759-762. doi: 10.1126/science.12 34274

Clancy, K. B., Schnepel, P., Rao, A. T., and Feldman, D. E. (2015). Structure of a single whisker representation in layer 2 of mouse somatosensory cortex. J. Neurosci. 35, 3946-3958. doi: 10.1523/JNEUROSCI.388714.2015

Constantinople, C. M., and Bruno, R. M. (2013). Deep cortical layers are activated directly by thalamus. Science 340, 1591-1594. doi: 10.1126/science. 1236425

Crochet, S., Poulet, J. F. A., Kremer, Y., and Petersen, C. C. H. (2011). Synaptic mechanisms underlying sparse coding of active touch. Neuron 69, 1160-1175. doi: 10.1016/j.neuron.2011.02.022

Cruikshank, S. J., Lewis, T. J., and Connors, B. W. (2007). Synaptic basis for intense thalamocortical activation of feedforward inhibitory cells in neocortex. Nat. Neurosci. 10, 462-468. doi: 10.1038/nn1861

Cruikshank, S. J., Urabe, H., Nurmikko, A. V., and Connors, B. W. (2010). Pathway-specific feedforward circuits between thalamus and neocortex revealed by selective optical stimulation of axons. Neuron 65, 230-245. doi: 10 . 1016/j.neuron.2009.12.025

Curtis, J. C., and Kleinfeld, D. (2009). Phase-to-rate transformations encode touch in cortical neurons of a scanning sensorimotor system. Nat. Neurosci. 12, 492-501. doi: 10.1038/nn.2283

Dávid, C., Schleicher, A., Zuschratter, W., and Staiger, J. F. (2007). The innervation of parvalbumin-containing interneurons by VIPimmunopositive interneurons in the primary somatosensory cortex of the adult rat. Eur. J. Neurosci. 25, 2329-2340. doi: 10.1111/j.1460-9568.2007. 05496.x

Daw, M. I., Ashby, M. C., and Isaac, J. T. R. (2007). Coordinated developmental recruitment of latent fast spiking interneurons in layer IV barrel cortex. Nat. Neurosci. 10, 453-461. doi: 10.1038/nn1866

DeFelipe, J., López-Cruz, P. L., Benavides-Piccione, R., Bielza, C., Larrañaga, P., Anderson, S., et al. (2013). New insights into the classification and nomenclature of cortical GABAergic interneurons. Nat. Rev. Neurosci. 14, 202-216. doi: 10.1038/nrn3444

de Kock, C. P. J., Bruno, R. M., Spors, H., and Sakmann, B. (2007). Layerand cell-type-specific suprathreshold stimulus representation in rat primary somatosensory cortex. J. Physiol. 581, 139-154. doi: 10.1113/jphysiol.2006. 124321

de Kock, C. P. J., and Sakmann, B. (2009). Spiking in primary somatosensory cortex during natural whisking in awake head-restrained rats is cell-type specific. Proc. Natl. Acad. Sci. U S A 106, 16446-16450. doi: 10.1073/pnas. 0904143106

DeNardo, L. A., Berns, D. S., DeLoach, K., and Luo, L. (2015). Connectivity of mouse somatosensory and prefrontal cortex examined with trans-synaptic tracing. Nat. Neurosci. 18, 1687-1697. doi: 10.1038/nn.4131

Elstrott, J., Clancy, K. B., Jafri, H., Akimenko, I., and Feldman, D. E. (2014). Cellular mechanisms for response heterogeneity among L2/3 pyramidal cells in whisker somatosensory cortex. J. Neurophysiol. 112, 233-248. doi: 10.1152/jn. 00848.2013

Fariñas, I., and DeFelipe, J. (1991). Patterns of synaptic input on corticocortical and corticothalamic cells in the cat visual cortex. II. The axon initial segment. J. Comp. Neurol. 304, 70-77. doi: 10.1002/cne.903040106

Feldmeyer, D., Roth, A., and Sakmann, B. (2005). Monosynaptic connections between pairs of spiny stellate cells in layer 4 and pyramidal cells in layer $5 \mathrm{~A}$ indicate that lemniscal and paralemniscal afferent pathways converge in the infragranular somatosensory cortex. J. Neurosci. 25, 3423-3431. doi: 10. 1523/JNEUROSCI.5227-04.2005

Fenno, L. E., Mattis, J., Ramakrishnan, C., Hyun, M., Lee, S. Y., He, M., et al. (2014). Targeting cells with single vectors using multiple-feature Boolean logic. Nat. Methods 11, 763-772. doi: 10.1038/nmeth.2996

Fino, E., Packer, A. M., and Yuste, R. (2013). The logic of inhibitory connectivity in the neocortex. Neuroscientist 19, 228-237. doi: 10.1177/1073858412456743

Fino, E., and Yuste, R. (2011). Dense inhibitory connectivity in neocortex. Neuron 69, 1188-1203. doi: 10.1016/j.neuron.2011.02.025

Frick, A., Feldmeyer, D., Helmstaedter, M., and Sakmann, B. (2008). Monosynaptic connections between pairs of L5A pyramidal neurons in 
columns of juvenile rat somatosensory cortex. Cereb. Cortex 18, 397-406. doi: $10.1093 /$ cercor/bhm074

Fu, Y., Tucciarone, J. M., Espinosa, J. S., Sheng, N., Darcy, D. P., Nicoll, R. A., et al. (2014). A cortical circuit for gain control by behavioral state. Cell 156, 1139-1152. doi: 10.1016/j.cell.2014.01.050

Gabernet, L., Jadhav, S. P., Feldman, D. E., Carandini, M., and Scanziani, M. (2005). Somatosensory integration controlled by dynamic thalamocortical feed-forward inhibition. Neuron 48, 315-327. doi: 10.1016/j.neuron.2005. 09.022

Galarreta, M., and Hestrin, S. (1998). Frequency-dependent synaptic depression and the balance of excitation and inhibition in the neocortex. Nat. Neurosci. 1, 587-594. doi: 10.1038/2822

Galarreta, M., and Hestrin, S. (1999). A network of fast-spiking cells in the neocortex connected by electrical synapses. Nature 402, 72-75. doi: 10 . $1038 / 47029$

Galarreta, M., and Hestrin, S. (2002). Electrical and chemical synapses among parvalbumin fast-spiking GABAergic interneurons in adult mouse neocortex. Proc. Natl. Acad. Sci. U S A 99, 12438-12443. doi: 10.1073/pnas.192 159599

Gentet, L. J. (2012). Functional diversity of supragranular GABAergic neurons in the barrel cortex. Front. Neural Circuits 6:52. doi: 10.3389/fncir.2012. 00052

Gentet, L. J., Kremer, Y., Taniguchi, H., Huang, Z. J., Staiger, J. F., and Petersen, C. C. H. (2012). Unique functional properties of somatostatinexpressing GABAergic neurons in mouse barrel cortex. Nat. Neurosci. 15, 607-612. doi: 10.1038/nn.3051

Gibson, J. R., Beierlein, M., and Connors, B. W. (1999). Two networks of electrically coupled inhibitory neurons in neocortex. Nature 402, 75-79. doi: 10. $1038 / 47035$

Glickfeld, L. L., Roberts, J. D., Somogyi, P., and Scanziani, M. (2009). Interneurons hyperpolarize pyramidal cells along their entire somatodendritic axis. Nat. Neurosci. 12, 21-23. doi: 10.1038/nn.2230

Gonchar, Y., Wang, Q., and Burkhalter, A. (2008). Multiple distinct subtypes of GABAergic neurons in mouse visual cortex identified by triple immunostaining. Front. Neuroanat. 1:3. doi: 10.3389/neuro.05. 003.2007

Gong, Y., Huang, C., Li, J. Z., Grewe, B. F., Zhang, Y., Eismann, S., et al. (2015). High-speed recording of neural spikes in awake mice and flies with a fluorescent voltage sensor. Science 350, 1361-1366. doi: 10.1126/science. aab0810

Greenhill, S. D., Ranson, A., and Fox, K. (2015). Hebbian and homeostatic plasticity mechanisms in regular spiking and intrinsic bursting cells of cortical layer 5. Neuron 88, 539-552. doi: 10.1016/j.neuron.2015. 09.025

Grewe, B. T., Bonnan, A., and Frick, A. (2010). Back-propagation of physiological action potential output in dendrites of slender-tufted L5A pyramidal neurons. Front. Cell. Neurosci. 4:13. doi: 10.3389/fncel.2010. 00013

Groh, A., Meyer, H. S., Schmidt, E. F., Heintz, N., Sakmann, B., and Krieger, P. (2010). Cell-type specific properties of pyramidal neurons in neocortex underlying a layout that is modifiable depending on the cortical area. Cereb. Cortex 20, 826-836. doi: 10.1093/cercor/bhp152

Grosenick, L., Marshel, J. H., and Deisseroth, K. (2015). Closed-loop and activityguided optogenetic control. Neuron 86, 106-139. doi: 10.1016/j.neuron.2015. 03.034

Gupta, A., Wang, Y., and Markram, H. (2000). Organizing principles for a diversity of GABAergic interneurons and synapses in the neocortex. Science 287, 273-278. doi: 10.1126/science.287.5451.273

Harris, K. D. (2013). Top-down control of cortical state. Neuron 79, 408-410. doi: 10.1016/j.neuron.2013.07.034

Harris, K. D., and Mrsic-Flogel, T. D. (2013). Cortical connectivity and sensory coding. Nature 503, 51-58. doi: 10.1038/nature12654

Harris, K. D., and Shepherd, G. M. G. (2015). The neocortical circuit: themes and variations. Nat. Neurosci. 18, 170-181. doi: 10.1038/ nn. 3917

Hattox, A. M., and Nelson, S. B. (2007). Layer V neurons in mouse cortex projecting to different targets have distinct physiological properties. J. Neurophysiol. 98, 3330-3340. doi: 10.1152/jn.00397.2007
Helmstaedter, M., Sakmann, B., and Feldmeyer, D. (2009a). L2/3 interneuron groups defined by multiparameter analysis of axonal projection, dendritic geometry and electrical excitability. Cereb. Cortex 19, 951-962. doi: 10. 1093/cercor/bhn130

Helmstaedter, M., Sakmann, B., and Feldmeyer, D. (2009b). Neuronal correlates of local, lateral and translaminar inhibition with reference to cortical columns. Cereb. Cortex 19, 926-937. doi: 10.1093/cercor/bhn141

Helmstaedter, M., Sakmann, B., and Feldmeyer, D. (2009c). The relation between dendritic geometry, electrical excitability and axonal projections of L2/3 interneurons in rat barrel cortex. Cereb. Cortex 19, 938-950. doi: 10. 1093/cercor/bhn138

Helmstaedter, M., Staiger, J. F., Sakmann, B., and Feldmeyer, D. (2008). Efficient recruitment of layer $2 / 3$ interneurons by layer 4 input in single columns of rat somatosensory cortex. J. Neurosci. 28, 8273-8284. doi: 10.1523/JNEUROSCI. 5701-07.2008

Hestrin, S., and Galarreta, M. (2005). Electrical synapses define networks of neocortical GABAergic neurons. Trends Neurosci. 28, 304-309. doi: 10.1016/j. tins.2005.04.001

Hioki, H., Okamoto, S., Konno, M., Kameda, H., Sohn, J., Kuramoto, E., et al. (2013). Cell type-specific inhibitory inputs to dendritic and somatic compartments of parvalbumin-expressing neocortical interneuron. J. Neurosci. 33, 544-555. doi: 10.1523/JNEUROSCI.2255-12.2013

Hires, S. A., Gutnisky, D. A., Yu, J., O’Connor, D. H., and Svoboda, K. (2015). Low-noise encoding of active touch by layer 4 in the somatosensory cortex. Elife 4:e06619. doi: 10.7554/eLife.06619

Hofer, S. B., Ko, H., Pichler, B., Vogelstein, J., Ros, H., Zeng, H., et al. (2011). Differential connectivity and response dynamics of excitatory and inhibitory neurons in visual cortex. Nat. Neurosci. 14, 1045-1052. doi: 10.1038/ nn. 2876

Hooks, B. M., Hires, S. A., Zhang, Y. X., Huber, D., Petreanu, L., Svoboda, K., et al. (2011). Laminar analysis of excitatory local circuits in vibrissal motor and sensory cortical areas. PLoS Biol. 9:e1000572. doi: 10.1371/journal.pbio. 1000572

Horton, N. G., Wang, K., Kobat, D., Clark, C. G., Wise, F. W., Schaffer, C. B., et al. (2013). In vivo three-photon microscopy of subcortical structures within an intact mouse brain. Nat. Photonics 7, 205-209. doi: 10.1038/nphoton. 2012.336

House, D. R. C., Elstrott, J., Koh, E., Chung, J., and Feldman, D. E. (2011). Parallel regulation of feedforward inhibition and excitation during whisker map plasticity. Neuron 72, 819-831. doi: 10.1016/j.neuron.2011.09.008

Hu, H., Cavendish, J. Z., and Agmon, A. (2013). Not all that glitters is gold: offtarget recombination in the somatostatin-IRES-Cre mouse line labels a subset of fast-spiking interneurons. Front. Neural Circuits 7:195. doi: 10.3389/fncir. 2013.00195

Hu, H., Gan, J., and Jonas, P. (2014). Fast-spiking, parvalbumin+ GABAergic interneurons: from cellular design to microcircuit function. Science 345:1255263. doi: $10.1126 /$ science. 1255263

Huang, Z. J. (2014). Toward a genetic dissection of cortical circuits in the mouse. Neuron 83, 1284-1302. doi: 10.1016/j.neuron.2014.08.041

Huang, Y.-L., Walker, A. S., and Miller, E. W. (2015). A photostable silicon rhodamine platform for optical voltage sensing. J. Am. Chem. Soc. 137, 10767-10776. doi: 10.1021/jacs.5b06644

Inda, M. C., DeFelipe, J., and Muñoz, A. (2009). Morphology and distribution of chandelier cell axon terminals in the mouse cerebral cortex and claustroamygdaloid complex. Cereb. Cortex 19, 41-54. doi: 10. 1093/cercor/bhn057

Inoue, M., Takeuchi, A., Horigane, S., Ohkura, M., Gengyo-Ando, K., Fujii, H., et al. (2014). Rational design of a high-affinity, fast, red calcium indicator RCaMP2. Nat. Methods 12, 64-70. doi: 10.1038/nmeth.3185

Isaacson, J. S., and Scanziani, M. (2011). How inhibition shapes cortical activity. Neuron 72, 231-243. doi: 10.1016/j.neuron.2011.09.027

Jacob, V., Petreanu, L., Wright, N., Svoboda, K., and Fox, K. (2012). Regular spiking and intrinsic bursting pyramidal cells show orthogonal forms of experience-dependent plasticity in layer V of barrel cortex. Neuron 73, 391-404. doi: 10.1016/j.neuron.2011.11.034

Jadhav, S. P., Wolfe, J., and Feldman, D. E. (2009). Sparse temporal coding of elementary tactile features during active whisker sensation. Nat. Neurosci. 12, 792-800. doi: $10.1038 / \mathrm{nn} .2328$ 
Ji, X.-Y., Zingg, B., Mesik, L., Xiao, Z., Zhang, L. I., and Tao, H. W. (2015). Thalamocortical innervation pattern in mouse auditory and visual cortex: laminar and cell-type specificity. Cereb. Cortex doi: 10.1093/cercor/bhv099 [Epub ahead of print].

Jiang, X., Shen, S., Cadwell, C. R., Berens, P., Sinz, F., Ecker, A. S., et al. (2015). Principles of connectivity among morphologically defined cell types in adult neocortex. Science 350:aac9462. doi: 10.1126/science.aac9462

Jiang, X., Wang, G., Lee, A. J., Stornetta, R. L., and Zhu, J. J. (2013). The organization of two new cortical interneuronal circuits. Nat. Neurosci. 16, 210-218. doi: 10.1038/nn.3305

Jin, X., Jiang, K., and Prince, D. A. (2014). Excitatory and inhibitory synaptic connectivity to layer $\mathrm{V}$ fast-spiking interneurons in the freeze lesion model of cortical microgyria. J. Neurophysiol. 122, 1703-1713. doi: 10.1152/jn.00854. 2013

Kampa, B. M., Letzkus, J. J., and Stuart, G. J. (2006). Cortical feed-forward networks for binding different streams of sensory information. Nat. Neurosci. 9, 1472-1473. doi: 10.1038/nn1798

Kapfer, C., Glickfeld, L. L., Atallah, B. V., and Scanziani, M. (2007). Supralinear increase of recurrent inhibition during sparse activity in the somatosensory cortex. Nat. Neurosci. 10, 743-753. doi: 10.1038/ nn1909

Karayannis, T., Huerta-Ocampo, I., and Capogna, M. (2006). GABAergic and pyramidal neurons of deep cortical layers directly receive and differently integrate callosal input. Cereb. Cortex 17, 1213-1226. doi: 10. 1093/cercor/bhl035

Karnani, M. M., Jackson, J., Ayzenshtat, I., Hamzehei Sichani, A., Manoocheri, K., Kim, S., et al. (2016a). Opening holes in the blanket of inhibition: localized lateral disinhibition by VIP interneurons. J. Neurosci. 36, 3471-3480. doi: 10. 1523/JNEUROSCI.3646-15.2016

Karnani, M. M., Jackson, J., Ayzenshtat, I., Tucciarone, J., Manoocheri, K., Snider, W. G., et al. (2016b). Cooperative subnetworks of molecularly similar interneurons in mouse neocortex. Neuron 90, 86-100. doi: 10.1016/j.neuron. 2016.02.037

Kätzel, D., Zemelman, B. V., Buetfering, C., Wölfel, M., and Miesenböck, G. (2011). The columnar and laminar organization of inhibitory connections to neocortical excitatory cells. Nat. Neurosci. 14, 100-107. doi: 10.1038/nn.2687

Kepecs, A., and Fishell, G. (2014). Interneuron cell types are fit to function. Nature 505, 318-326. doi: 10.1038/nature 12983

Kerlin, A. M., Andermann, M. L., Berezovskii, V. K., and Reid, R. C. (2010). Broadly tuned response properties of diverse inhibitory neuron subtypes in mouse visual cortex. Neuron 67, 858-871. doi: 10.1016/j.neuron.2010. 08.002

Kerr, J. N., de Kock, C. P. J., Greenberg, D. S., Bruno, R. M., Sakmann, B., and Helmchen, F. (2007). Spatial organization of neuronal population responses in layer 2/3 of rat barrel cortex. J. Neurosci. 27, 13316-13328. doi: 10. 1523/jneurosci.2210-07.2007

Kim, E. J., Juavinett, A. L., Kyubwa, E. M., Jacobs, M. W., Callaway, E. M., Kim, E. J., et al. (2015). Three types of cortical layer 5 neurons that differ in brain-wide connectivity and function. Neuron 88, 1253-1267. doi: 10.1016/j. neuron.2015.11.002

Kim, J., Matney, C. J., Blankenship, A., Hestrin, S., and Brown, S. P. (2014). Layer 6 corticothalamic neurons activate a cortical output layer, layer 5a. J. Neurosci. 34, 9656-9664. doi: 10.1523/JNEUROSCI.1325-14.2014

Kinnischtzke, A. K., Simons, D. J., and Fanselow, E. E. (2014). Motor cortex broadly engages excitatory and inhibitory neurons in somatosensory barrel cortex. Cereb. Cortex 24, 2237-2248. doi: 10.1093/cercor/bht085

Kiritani, T., Wickersham, I. R., Seung, H. S., and Shepherd, G. M. G. (2012). Hierarchical connectivity and connection-specific dynamics in the corticospinal-corticostriatal microcircuit in mouse motor cortex. J. Neurosci. 32, 4992-5001. doi: 10.1523/JNEUROSCI.4759-11.2012

Krieger, P., Kuner, T., and Sakmann, B. (2007). Synaptic connections between layer $5 \mathrm{~B}$ pyramidal neurons in mouse somatosensory cortex are independent of apical dendrite bundling. J. Neurosci. 27, 11473-11482. doi: 10.1523/jneurosci. 1182-07.2007

Kruglikov, I., and Rudy, B. (2008). Perisomatic GABA release and thalamocortical integration onto neocortical excitatory cells are regulated by neuromodulators. Neuron 58, 911-924. doi: 10.1016/j.neuron.2008. 04.024
Krupa, D. J., Wiest, M. C., Shuler, M. G., Laubach, M., and Nicolelis, M. A. L. (2004). Layer-specific somatosensory cortical activation during active tactile discrimination. Science 304, 1989-1992. doi: 10.1126/science. 1093318

Kubota, Y. (2014). Untangling GABAergic wiring in the cortical microcircuit. Curr. Opin. Neurobiol. 26, 7-14. doi: 10.1016/j.conb.2013. 10.003

Kubota, Y., Shigematsu, N., Karube, F., Sekigawa, A., Kato, S., Yamaguchi, N., et al. (2011). Selective coexpression of multiple chemical markers defines discrete populations of neocortical gabaergic neurons. Cereb. Cortex 21, 1803-1817. doi: 10.1093/cercor/bhq252

Kumar, A., Vlachos, I., Aertsen, A., and Boucsein, C. (2013). Challenges of understanding brain function by selective modulation of neuronal subpopulations. Trends Neurosci. 36, 579-586. doi: 10.1016/j.tins.2013. 06.005

Kwan, A. C., and Dan, Y. (2012). Dissection of cortical microcircuits by singleneuron stimulation in vivo. Curr. Biol. 22, 1459-1467. doi: 10.1016/j.cub.2012. 06.007

Larkum, M. (2013). A cellular mechanism for cortical associations: an organizing principle for the cerebral cortex. Trends Neurosci. 36, 141-151. doi: 10.1016/j. tins.2012.11.006

Larkum, M. E., Kaiser, K. M. M., and Sakmann, B. (1999a). Calcium electrogenesis in distal apical dendrites of layer 5 pyramidal cells at a critical frequency of back-propagating action potentials. Proc. Natl. Acad. Sci. U S A 96, 14600-14604. doi: 10.1073/pnas.96.25.14600

Larkum, M. E., Nevian, T., Sandler, M., Polsky, A., and Schiller, J. (2009). Synaptic integration in tuft dendrites of layer 5 pyramidal neurons: a new unifying principle. Science 325, 756-760. doi: 10.1126/science.1171958

Larkum, M. E., Senn, W., and Lüscher, H.-R. (2004). Top-down dendritic input increases the gain of layer 5 pyramidal neurons. Cereb. Cortex 14, 1059-1070. doi: 10.1093/cercor/bhh065

Larkum, M. E., and Zhu, J. J. (2002). Signaling of layer 1 and whisker-evoked $\mathrm{Ca}^{2+}$ and $\mathrm{Na}^{+}$action potentials in distal and terminal dendrites of rat neocortical pyramidal neurons in vitro and in vivo. J. Neurosci. 22, 69917005 .

Larkum, M. E., Zhu, J. J., and Sakmann, B. (1999b). A new cellular mechanism for coupling inputs arriving at different cortical layers. Nature 398, 338-341. doi: $10.1038 / 18686$

Larsen, D. D., and Callaway, E. M. (2006). Development of layer-specific axonal arborizations in mouse primary somatosensory cortex. J. Comp. Neurol. 494, 398-414. doi: 10.1002/cne.20754

Larsen, D. D., Wickersham, I. R., and Callaway, E. M. (2008). Retrograde tracing with recombinant rabies virus reveals correlations between projection targets and dendritic architecture in layer 5 of mouse barrel cortex. Front. Neural Circuits 1:5. doi: 10.3389/neuro.04. 005.2007

Lavzin, M., Rapoport, S., Polsky, A., Garion, L., and Schiller, J. (2012). Nonlinear dendritic processing determines angular tuning of barrel cortex neurons in vivo. Nature 490, 397-401. doi: 10.1038/nature11451

Leão, R. N., Mikulovic, S., Leão, K. E., Munguba, H., Gezelius, H., Enjin, A., et al. (2012). OLM interneurons differentially modulate CA3 and entorhinal inputs to hippocampal CA1 neurons. Nat. Neurosci. 15, 1524-1530. doi: 10.1038/nn. 3235

Le Bé, J.-V., Silberberg, G., Wang, Y., and Markram, H. (2007). Morphological, electrophysiological and synaptic properties of corticocallosal pyramidal cells in the neonatal rat neocortex. Cereb. Cortex 17, 2204-2213. doi: 10. 1093/cercor/bhl127

Lee, A. T., Gee, S. M., Vogt, D., Patel, T., Rubenstein, J. L., and Sohal, V. S. (2014). Pyramidal neurons in prefrontal cortex receive subtype-specific forms of excitation and inhibition. Neuron 81, 61-68. doi: 10.1016/j.neuron.2013. 10.031

Lee, S., Hjerling-Leffler, J., Zagha, E., Fishell, G., and Rudy, B. (2010). The largest group of superficial neocortical GABAergic interneurons expresses ionotropic serotonin receptors. J. Neurosci. 30, 16796-16808. doi: 10.1523/JNEUROSCI. $1869-10.2010$

Lee, S., Kruglikov, I., Huang, Z. J., Fishell, G., and Rudy, B. (2013). A disinhibitory circuit mediates motor integration in the somatosensory cortex. Nat. Neurosci. 16, 1662-1670. doi: 10.1038/nn.3544 
Lee, S.-H., Kwan, A. C., Zhang, S., Phoumthipphavong, V., Flannery, J. G., Masmanidis, S. C., et al. (2012). Activation of specific interneurons improves V1 feature selectivity and visual perception. Nature 488, 379-383. doi: 10. 1038/nature11312

Lee, A. J., Wang, G., Jiang, X., Johnson, S. M., Hoang, E. T., Lanté, F., et al. (2015). Canonical organization of layer 1 neuron-led cortical inhibitory and disinhibitory interneuronal circuits. Cereb. Cortex 25, 2114-2126. doi: 10. 1093/cercor/bhu020

Lefort, S., Tomm, C., Floyd Sarria, J.-C., and Petersen, C. C. H. (2009). The excitatory neuronal network of the $\mathrm{C} 2$ barrel column in mouse primary somatosensory cortex. Neuron 61, 301-316. doi: 10.1016/j.neuron.2008.12.020

Lévesque, M., Charara, A., Gagnon, S., Parent, A., and Deschênes, M. (1996). Corticostriatal projections from layer $\mathrm{V}$ cells in rat are collaterals of longrange corticofugal axons. Brain Res. 709, 311-315. doi: 10.1016/0006-8993(95) 01333-4

Li, L.-Y., Ji, X.-Y., Liang, F., Li, Y.-T., Xiao, Z., Tao, H. W., et al. (2014). A feedforward inhibitory circuit mediates lateral refinement of sensory representation in upper layer $2 / 3$ of mouse primary auditory cortex. J. Neurosci. 34, 13670-13683. doi: 10.1523/JNEUROSCI.1516-14.2014

Litwin-Kumar, A., Rosenbaum, R., and Doiron, B. (2016). Inhibitory stabilization and visual coding in cortical circuits with multiple interneuron subtypes. J. Neurophysiol. 115, 1399-1409. doi: 10.1152/jn.00732.2015

Lur, G., Vinck, M. A., Tang, L., Cardin, J. A., and Higley, M. J. (2016). Projectionspecific visual feature encoding by layer 5 cortical subnetworks. Cell Rep. 14, 2538-2545. doi: 10.1016/j.celrep.2016.02.050

Ma, Y., Hu, H., and Agmon, A. (2012). Short-term plasticity of unitary inhibitoryto-inhibitory synapses depends on the presynaptic interneuron subtype. J. Neurosci. 32, 983-988. doi: 10.1523/JNEUROSCI.5007-11.2012

Ma, Y., Hu, H., Berrebi, A. S., Mathers, P. H., and Agmon, A. (2006). Distinct subtypes of somatostatin-containing neocortical interneurons revealed in transgenic mice. J. Neurosci. 26, 5069-5082. doi: 10.1523/jneurosci.0661-06. 2006

Ma, W., Liu, B., Li, Y., Huang, Z. J., Zhang, L. I., and Tao, H. W. (2010). Visual representations by cortical somatostatin inhibitory neurons-selective but with weak and delayed responses. J. Neurosci. 30, 14371-14379. doi: 10. 1523/JNEUROSCI.3248-10.2010

Madisen, L., Garner, A. R., Shimaoka, D., Chuong, A. S., Klapoetke, N. C., Li, L., et al. (2015). Transgenic mice for intersectional targeting of neural sensors and effectors with high specificity and performance. Neuron 85, 942-958. doi: 10 . 1016/j.neuron.2015.02.022

Major, G., Larkum, M. E., and Schiller, J. (2013). Active properties of neocortical pyramidal neuron dendrites. Annu. Rev. Neurosci. 36, 1-24. doi: 10. 1146/annurev-neuro-062111-150343

Manita, S., Suzuki, T., Homma, C., Matsumoto, T., Odagawa, M., Yamada, K., et al. (2015). A top-down cortical circuit for accurate sensory perception. Neuron 86, 1304-1316. doi: 10.1016/j.neuron.2015.05.006

Manns, I. D., Sakmann, B., and Brecht, M. (2004). Sub- and suprathreshold receptive field properties of pyramidal neurones in layers $5 \mathrm{~A}$ and $5 \mathrm{~B}$ of rat somatosensory barrel cortex. J. Physiol. 556, 601-622. doi: 10.1113/jphysiol. 2003.053132

Mao, T., Kusefoglu, D., Hooks, B. M., Huber, D., Petreanu, L., and Svoboda, K. (2011). Long-range neuronal circuits underlying the interaction between sensory and motor cortex. Neuron 72, 111-123. doi: 10.1016/j.neuron.2011. 07.029

Markram, H. (1997). A network of tufted layer 5 pyramidal neurons. Cereb. Cortex 7, 523-533. doi: 10.1093/cercor/7.6.523

Markram, H., Muller, E., Ramaswamy, S., Reimann, M. W., Abdellah, M., Sanchez, C. A., et al. (2015). Reconstruction and simulation of neocortical microcircuitry. Cell 163, 456-492. doi: 10.1016/j.cell.2015.09.029

Markram, H., Toledo-Rodriguez, M., Wang, Y., Gupta, A., Silberberg, G., and $\mathrm{Wu}$, C. (2004). Interneurons of the neocortical inhibitory system. Nat. Rev. Neurosci. 5, 793-807. doi: 10.1038/nrn1519

Marlin, J. J., and Carter, A. G. (2014). GABA-A receptor inhibition of local calcium signaling in spines and dendrites. J. Neurosci. 34, 15898-15911. doi: 10. 1523/JNEUROSCI.0869-13.2014

Marques-Smith, A., Lyngholm, D., Kaufmann, A.-K., Stacey, J. A., HoerderSuabedissen, A., Becker, E. B. E., et al. (2016). A transient translaminar GABAergic interneuron circuit connects thalamocortical recipient layers in neonatal somatosensory cortex. Neuron 89, 536-549. doi: 10.1016/j.neuron. 2016.01.015

McGarry, L. M., Packer, A. M., Fino, E., Nikolenko, V., Sippy, T., and Yuste, R. (2010). Quantitative classification of somatostatin-positive neocortical interneurons identifies three interneuron subtypes. Front. Neural Circuits 4:12. doi: 10.3389/fncir.2010.00012

Meyer, H. S., Schwarz, D., Wimmer, V. C., Schmitt, A. C., Kerr, J. N. D., Sakmann, B., et al. (2011). Inhibitory interneurons in a cortical column form hot zones of inhibition in layers 2 and 5A. Proc. Natl. Acad. Sci. U S A 108, 16807-16812. doi: 10.1073/pnas.1113648108

Meyer, H. S., Wimmer, V. C., Hemberger, M., Bruno, R. M., de Kock, C. P. J., Frick, A., et al. (2010). Cell type-specific thalamic innervation in a column of rat vibrissal cortex. Cereb. Cortex 20, 2287-2303. doi: 10.1093/cercor/bhq069

Mittmann, W., Wallace, D. J., Czubayko, U., Herb, J. T., Schaefer, A. T., Looger, L. L., et al. (2011). Two-photon calcium imaging of evoked activity from L5 somatosensory neurons in vivo. Nat. Neurosci. 14, 1089-1093. doi: 10. 1038/nn.2879

Müllner, F. E., Wierenga, C. J., and Bonhoeffer, T. (2015). Precision of inhibition: dendritic inhibition by individual GABAergic synapses on hippocampal pyramidal cells is confined in space and time. Neuron 87, 576-589. doi: 10. 1016/j.neuron.2015.07.003

Murayama, M., Pérez-Garci, E., Nevian, T., Bock, T., Senn, W., and Larkum, M. E. (2009). Dendritic encoding of sensory stimuli controlled by deep cortical interneurons. Nature 457, 1137-1141. doi: 10.1038/nature07663

Naka, A. (2015). Cell-type-specific manipulation reveals new specificity in the neocortical microcircuit. J. Neurosci. 35, 8976-8978. doi: 10.1523/jneurosci. 1297-15.2015

Narayanan, R. T., Egger, R., Johnson, A. S., Mansvelder, H. D., Sakmann, B., de Kock, C. P. J., et al. (2015). Beyond columnar organization: cell type- and target layer-specific principles of horizontal axon projection patterns in rat vibrissal cortex. Cereb. Cortex 25, 4450-4468. doi: 10.1093/cercor/bhv053

Oberlaender, M., Boudewijns, Z. S. R. M., Kleele, T., Mansvelder, H. D., Sakmann, B., and de Kock, C. P. J. (2011). Three-dimensional axon morphologies of individual layer 5 neurons indicate cell type-specific intracortical pathways for whisker motion and touch. Proc. Natl. Acad. Sci. US A 108, 4188-4193. doi: 10.1073/pnas.1100647108

Oberlaender, M., de Kock, C. P. J., Bruno, R. M., Ramirez, A., Meyer, H. S., Dercksen, V. J., et al. (2012). Cell type-specific three-dimensional structure of thalamocortical circuits in a column of rat vibrissal cortex. Cereb. Cortex 22 , 2375-2391. doi: 10.1093/cercor/bhr317

O’Connor, D. H., Peron, S. P., Huber, D., and Svoboda, K. (2010). Neural activity in barrel cortex underlying vibrissa-based object localization in mice. Neuron 67, 1048-1061. doi: 10.1016/j.neuron.2010.08.026

Oláh, S., Füle, M., Komlósi, G., Varga, C., Báldi, R., Barzó, P., et al. (2009). Regulation of cortical microcircuits by unitary GABA-mediated volume transmission. Nature 461, 1278-1281. doi: 10.1038/nature08503

Olsen, S. R., Bortone, D. S., Adesnik, H., and Scanziani, M. (2012). Gain control by layer six in cortical circuits of vision. Nature 483, 47-52. doi: 10 . 1038/nature 10835

Otsuka, T., and Kawaguchi, Y. (2009). Cortical inhibitory cell types differentially form intralaminar and interlaminar subnetworks with excitatory neurons. J. Neurosci. 29, 10533-10540. doi: 10.1523/jneurosci.2219-09.2009

Otsuka, T., and Kawaguchi, Y. (2013). Common excitatory synaptic inputs to electrically connected cortical fast-spiking cell networks. J. Neurophysiol. 110, 795-806. doi: 10.1152/jn.00071.2013

Packer, A. M., and Yuste, R. (2011). Dense, unspecific connectivity of neocortical parvalbumin-positive interneurons: a canonical microcircuit for inhibition? J. Neurosci. 31, 13260-13271. doi: 10.1523/jneurosci.3131-11.2011

Palmer, L. M., Schulz, J. M., and Larkum, M. E. (2013). Layer-specific regulation of cortical neurons by interhemispheric inhibition. Commun. Integr. Biol. 6:e23545. doi: 10.4161/cib.23545

Palmer, L. M., Schulz, J. M., Murphy, S. C., Ledergerber, D., Murayama, M., and Larkum, M. E. (2012). The cellular basis of GABA(B)-mediated interhemispheric inhibition. Science 335, 989-993. doi: 10.1126/science. 1217276

Perin, R., Berger, T. K., and Markram, H. (2011). A synaptic organizing principle for cortical neuronal groups. Proc. Natl. Acad. Sci. U S A 108, 5419-5424. doi: 10.1073/pnas.1016051108 
Peron, S. P., Freeman, J., Iyer, V., Guo, C., and Svoboda, K. (2015). A cellular resolution map of barrel cortex activity during tactile behavior. Neuron 86, 783-799. doi: 10.1016/j.neuron.2015.03.027

Peters, A., Proskauer, C. C., and Ribak, C. E. (1982). Chandelier cells in rat visual cortex. J. Comp. Neurol. 206, 397-416. doi: 10.1002/cne.902060408

Petersen, C. C. H. (2014). Cell-type specific function of GABAergic neurons in layers 2 and 3 of mouse barrel cortex. Curr. Opin. Neurobiol. 26, 1-6. doi: 10. 1016/j.conb.2013.10.004

Petersen, C. C. H., and Crochet, S. (2013). Synaptic computation and sensory processing in neocortical layer $2 / 3$. Neuron $78,28-48$. doi: $10.1016 / j$. neuron. 2013.03.020

Petersen, R. S., Panzeri, S., and Diamond, M. E. (2002). Population coding in somatosensory cortex. Curr. Opin. Neurobiol. 12, 441-447. doi: 10.1016/s09594388(02)00338-0

Petreanu, L., Gutnisky, D. A., Huber, D., Xu, N., O’Connor, D. H., Tian, L., et al. (2012). Activity in motor-sensory projections reveals distributed coding in somatosensation. Nature 489, 299-303. doi: 10.1038/nature11321

Petreanu, L., Huber, D., Sobczyk, A., and Svoboda, K. (2007). Channelrhodopsin2 -assisted circuit mapping of long-range callosal projections. Nat. Neurosci. 10, 663-668. doi: 10.1038/nn1891

Petreanu, L., Mao, T., Sternson, S. M., and Svoboda, K. (2009). The subcellular organization of neocortical excitatory connections. Nature 457, 1142-1145. doi: 10.1038/nature07709

Pfeffer, C. K., Xue, M., He, M., Huang, Z. J., and Scanziani, M. (2013). Inhibition of inhibition in visual cortex: the logic of connections between molecularly distinct interneurons. Nat. Neurosci. 16, 1068-1076. doi: 10.1038/ nn. 3446

Pi, H.-J., Hangya, B., Kvitsiani, D., Sanders, J. I., Huang, Z. J., and Kepecs, A. (2013). Cortical interneurons that specialize in disinhibitory control. Nature 503, 521-524. doi: 10.1038/nature12676

Pitas, A., Albarracín, A. L., Molano-Mazón, M., and Maravall, M. (2016). Variable temporal integration of stimulus patterns in the mouse barrel cortex. Cereb. Cortex doi: 10.1093/cercor/bhw006 [Epub ahead of print].

Pluta, S., Naka, A., Veit, J., Telian, G., Yao, L., Hakim, R., et al. (2015). A direct translaminar inhibitory circuit tunes cortical output. Nat. Neurosci. 18, 1631-1640. doi: 10.1038/nn.4123

Polack, P. O., Friedman, J., and Golshani, P. (2013). Cellular mechanisms of brain state-dependent gain modulation in visual cortex. Nat. Neurosci. 16, 1-11. doi: $10.1038 / \mathrm{nn} .3464$

Porter, J. T., Johnson, C. K., and Agmon, A. (2001). Diverse types of interneurons generate thalamus-evoked feedforward inhibition in the mouse barrel cortex. J. Neurosci. 21, 2699-2710.

Pouille, F., Marin-Burgin, A., Adesnik, H., Atallah, B. V., and Scanziani, M. (2009). Input normalization by global feedforward inhibition expands cortical dynamic range. Nat. Neurosci. 12, 1577-1585. doi: 10.1038/nn.2441

Pouille, F., and Scanziani, M. (2001). Enforcement of temporal fidelity in pyramidal cells by somatic feed-forward inhibition. Science 293, 1159-1163. doi: $10.1126 /$ science. 1060342

Pouille, F., and Scanziani, M. (2004). Routing of spike series by dynamic circuits in the hippocampus. Nature 429, 717-723. doi: 10.1038/nature02615

Prönneke, A., Scheuer, B., Wagener, R. J., Möck, M., Witte, M., and Staiger, J. F. (2015). Characterizing VIP neurons in the barrel cortex of VIPcre/tdTomato mice reveals layer-specific differences. Cereb. Cortex 25, 4854-4868. doi: 10. 1093/cercor/bhv202

Rah, J.-C., Bas, E., Colonell, J., Mishchenko, Y., Karsh, B., Fetter, R. D., et al. (2013). Thalamocortical input onto layer 5 pyramidal neurons measured using quantitative large-scale array tomography. Front. Neural Circuits 7:177. doi: 10. 3389/fncir.2013.00177

Ramaswamy, S., and Markram, H. (2015). Anatomy and physiology of the thicktufted layer 5 pyramidal neuron. Front. Cell. Neurosci. 9:233. doi: 10.3389/fncel. 2015.00233

Reimer, J., Froudarakis, E., Cadwell, C. R., Yatsenko, D., Denfield, G. H., and Tolias, A. S. (2014). Pupil fluctuations track fast switching of cortical states during quiet wakefulness. Neuron 84, 355-362. doi: 10.1016/j.neuron.2014. 09.033

Reyes, A., Lujan, R., Rozov, A., Burnashev, N., Somogyi, P., and Sakmann, B. (1998). Target-cell-specific facilitation and depression in neocortical circuits. Nat. Neurosci. 1, 279-285. doi: 10.1038/1092
Reyes-Puerta, V., Kim, S., Sun, J. J., Imbrosci, B., Kilb, W., and Luhmann, H. J. (2015a). High stimulus-related information in barrel cortex inhibitory interneurons. PLoS Comput. Biol. 11:e1004121. doi: 10.1371/journal.pcbi. 1004121

Reyes-Puerta, V., Sun, J.-J., Kim, S., Kilb, W., and Luhmann, H. J. (2015b). Laminar and columnar structure of sensory-evoked multineuronal spike sequences in adult rat barrel cortex in vivo. Cereb. Cortex 25, 2001-2021. doi: 10. 1093/cercor/bhu007

Rock, C., and Apicella, A. J. (2015). Callosal projections drive neuronal-specific responses in the mouse auditory cortex. J. Neurosci. 35, 6703-6713. doi: 10. 1523/jneurosci.5049-14.2015

Roux, L., and Buzsáki, G. (2015). Tasks for inhibitory interneurons in intact brain circuits. Neuropharmacology 88, 10-23. doi: 10.1016/j.neuropharm.2014. 09.011

Rubin, D. B., Van Hooser, S. D., and Miller, K. D. (2015). The stabilized supralinear network: a unifying circuit motif underlying multi-input integration in sensory cortex. Neuron 85, 402-417. doi: 10.1016/j.neuron.2014.12.026

Rudy, B., Fishell, G., Lee, S., and Hjerling-Leffler, J. (2011). Three groups of interneurons account for nearly $100 \%$ of neocortical GABAergic neurons. Dev. Neurobiol. 71, 45-61. doi: 10.1002/dneu.20853

Runyan, C. A., Schummers, J., Van Wart, A., Kuhlman, S. J., Wilson, N. R., Huang, Z. J., et al. (2010). Response features of parvalbumin-expressing interneurons suggest precise roles for subtypes of inhibition in visual cortex. Neuron 67, 847-857. doi: 10.1016/j.neuron.2010.08.006

Sakata, S., and Harris, K. D. (2009). Laminar structure of spontaneous and sensoryevoked population activity in auditory cortex. Neuron 64, 404-418. doi: 10. 1016/j.neuron.2009.09.020

Schnepel, P., Kumar, A., Zohar, M., Aertsen, A., and Boucsein, C. (2015). Physiology and impact of horizontal connections in rat neocortex. Cereb. Cortex 25, 3818-3835. doi: 10.1093/cercor/bhu265

Scholl, B., Pattadkal, J. J., Dilly, G. A., Priebe, N. J., and Zemelman, B. V. (2015). Local integration accounts for weak selectivity of mouse neocortical parvalbumin interneurons. Neuron 87, 424-436. doi: 10.1016/j.neuron.2015. 06.030

Schubert, D., Kötter, R., Luhmann, H. J., and Staiger, J. F. (2006). Morphology, electrophysiology and functional input connectivity of pyramidal neurons characterizes a genuine layer va in the primary somatosensory cortex. Cereb. Cortex 16, 223-236. doi: 10.1093/cercor/ bhi100

Schubert, D., Staiger, J. F., Cho, N., Kötter, R., Zilles, K., and Luhmann, H. J. (2001). Layer-specific intracolumnar and transcolumnar functional connectivity of layer $\mathrm{V}$ pyramidal cells in rat barrel cortex. J. Neurosci. 21, 3580-3592.

Seybold, B. A., Phillips, E. A. K., Schreiner, C. E., and Hasenstaub, A. R. (2015). Inhibitory actions unified by network integration. Neuron 87, 1181-1192. doi: 10.1016/j.neuron.2015.09.013

Shima, Y., Sugino, K., Hempel, C., Shima, M., Taneja, P., Bullis, J. B., et al. (2016). A mammalian enhancer trap resource for discovering and manipulating neuronal cell types. Elife 5:e13503. doi: 10.7554/elife.13503

Silberberg, G. (2008). Polysynaptic subcircuits in the neocortex: spatial and temporal diversity. Curr. Opin. Neurobiol. 18, 332-337. doi: 10.1016/j.conb. 2008.08.009

Silberberg, G., and Markram, H. (2007). Disynaptic inhibition between neocortical pyramidal cells mediated by Martinotti cells. Neuron 53, 735-746. doi: 10 1016/j.neuron.2007.02.012

Sofroniew, N. J., Vlasov, Y. A., Andrew Hires, S., Freeman, J., and Svoboda, K. (2015). Neural coding in barrel cortex during whisker-guided locomotion. Elife 4:e12559. doi: 10.7554/elife.12559

Sohn, J., Hioki, H., Okamoto, S., and Kaneko, T. (2014). Preprodynorphinexpressing neurons constitute a large subgroup of somatostatin-expressing GABAergic interneurons in the mouse neocortex. J. Comp. Neurol. 522, 1506-1526. doi: 10.1002/cne.23477

Song, S., Sjöström, P. J., Reigl, M., Nelson, S., and Chklovskii, D. B. (2005). Highly nonrandom features of synaptic connectivity in local cortical circuits. PLoS Biol. 3:e68. doi: 10.1371/journal.pbio.0030068

Staiger, J. F., Freund, T. F., and Zilles, K. (1997). Interneurons immunoreactive for vasoactive intestinal polypeptide (VIP) are extensively innervated by parvalbumin-containing boutons in rat primary somatosensory 
cortex. Eur. J. Neurosci. 9, 2259-2268. doi: 10.1111/j.1460-9568.1997. tb01644.x

Staiger, J. F., Schubert, D., Zuschratter, W., Kotter, R., and Luhmann, H. J. (2002). Innervation of interneurons immunoreactive for VIP by intrinsically bursting pyramidal cells and fast-spiking interneurons in infragranular layers of juvenile rat neocortex. Eur. J. Neurosci. 16, 11-20. doi: 10.1046/j.1460-9568.2002. 02048.x

Stokes, C. C. A., and Isaacson, J. S. (2010). From dendrite to soma: dynamic routing of inhibition by complementary interneuron microcircuits in olfactory cortex. Neuron 67, 452-465. doi: 10.1016/j.neuron.2010.06.029

Sun, Q.-Q., Huguenard, J. R., and Prince, D. A. (2006). Barrel cortex microcircuits: thalamocortical feedforward inhibition in spiny stellate cells is mediated by a small number of fast-spiking interneurons. J. Neurosci. 26, 1219-1230. doi: 10. 1523/jneurosci.4727-04.2006

Sun, Y. J., Kim, Y.-J., Ibrahim, L. A., Tao, H. W., and Zhang, L. I. (2013). Synaptic mechanisms underlying functional dichotomy between intrinsic-bursting and regular-spiking neurons in auditory cortical layer 5. J. Neurosci. 33, 5326-5339. doi: 10.1523/jneurosci.4810-12.2013

Swadlow, H. A. (2003). Fast-spike interneurons and feedforward inhibition in awake sensory neocortex. Cereb. Cortex 13, 25-32. doi: 10.1093/cercor/ 13.1.25

Szabadics, J., Varga, C., Molnár, G., Oláh, S., Barzó, P., and Tamás, G. (2006). Excitatory effect of GABAergic. Science 311, 233-235. doi: 10.1126/science. 1121325

Tan, Z., Hu, H., Huang, Z. J., and Agmon, A. (2008). Robust but delayed thalamocortical activation of dendritic-targeting inhibitory interneurons. Proc. Natl. Acad. Sci. U S A 105, 2187-2192. doi: 10.1073/pnas.07106 28105

Tang, J. C. Y., Rudolph, S., Dhande, O. S., Abraira, V. E., Choi, S., Lapan, S. W., et al. (2015). Cell type-specific manipulation with GFP-dependent Cre recombinase. Nat. Neurosci. 18, 1334-1341. doi: 10.1038/nn.4081

Taniguchi, H. (2014). Genetic dissection of GABAergic neural circuits in mouse neocortex. Front. Cell. Neurosci. 8:8. doi: 10.3389/fncel.2014.00008

Taniguchi, H., He, M., Wu, P., Kim, S., Paik, R., Sugino, K., et al. (2011). A resource of cre driver lines for genetic targeting of GABAergic neurons in cerebral cortex. Neuron 71, 995-1013. doi: 10.1016/j.neuron.2011.07.026

Taniguchi, H., Lu, J., and Huang, Z. J. (2013). The spatial and temporal origin of chandelier cells in mouse neocortex. Science 339, 70-74. doi: 10.1126/science. 1227622

Tasic, B., Menon, V., Nguyen, T., Kim, T., Levi, B., Yao, Z., et al. (2016). Adult cortical cell taxonomy by single cell transcriptomics. Nat. Neurosci. 19, 335-346. doi: 10.1038/nn.4216

Tuncdemir, S. N., Wamsley, B., Stam, F. J., Osakada, F., Goulding, M., Callaway, E. M., et al. (2016). Early somatostatin interneuron connectivity mediates the maturation of deep layer cortical circuits. Neuron 89, 521-535. doi: 10.1016/j.neuron.2015.11.020

Urban-Ciecko, J., Fanselow, E. E., and Barth, A. L. (2015). Neocortical somatostatin neurons reversibly silence excitatory transmission via GABAb receptors. Curr. Biol. 25, 722-731. doi: 10.1016/j.cub.2015.01.035

Veinante, P., Lavallée, P., and Deschênes, M. (2000). Corticothalamic projections from layer 5 of the vibrissal barrel cortex in the rat. J. Comp. Neurol. 424, 197-204. doi: 10.1002/1096-9861(20000821)424:2<197::aid-cne1>3. $0 . \operatorname{co} ; 2-6$

Vucurovic, K., Gallopin, T., Ferezou, I., Rancillac, A., Chameau, P., van Hooft, J. A., et al. (2010). Serotonin 3A receptor subtype as an early and protracted marker of cortical interneuron subpopulations. Cereb. Cortex 20, 2333-2347. doi: 10.1093/cercor/bhp310

Walker, F. (2016). Functional connectivity of layer II/III and V GABAergic Martinotti cells in the primary somatosensory (barrel) cortex of mice [dissertation]. Georg. Univ. Sch. Sci. 1-94.

Wang, Y., Gupta, A., Toledo-Rodriguez, M., Wu, C. Z., and Markram, H. (2002). Anatomical, physiological, molecular and circuit properties of nest basket cells in the developing somatosensory cortex. Cereb. Cortex 12, 395-410. doi: 10. 1093/cercor/12.4.395

Wang, K., Sun, W., Richie, C. T., Harvey, B. K., Betzig, E., and Ji, N. (2015). Direct wavefront sensing for high-resolution in vivo imaging in scattering tissue. Nat. Commun. 6:7276. doi: 10.1038/ncomms8276
Wang, Y., Toledo-Rodriguez, M., Gupta, A., Wu, C., Silberberg, G., Luo, J., et al. (2004). Anatomical, physiological and molecular properties of Martinotti cells in the somatosensory cortex of the juvenile rat. J. Physiol. 561, 65-90. doi: 10. 1113/jphysiol.2004.073353

Wilent, W. B., and Contreras, D. (2005). Dynamics of excitation and inhibition underlying stimulus selectivity in rat somatosensory cortex. Nat. Neurosci. 8, 1364-1370. doi: 10.1038/nn1545

Williams, S. R., and Mitchell, S. J. (2008). Direct measurement of somatic voltage clamp errors in central neurons. Nat. Neurosci. 11, 790-798. doi: 10.1038/nn. 2137

Wilson, N. R., Runyan, C. A., Wang, F. L., and Sur, M. (2012). Division and subtraction by distinct cortical inhibitory networks in vivo. Nature 488 , 343-348. doi: 10.1038/nature11347

Wimmer, V. C., Bruno, R. M., de Kock, C. P. J., Kuner, T., and Sakmann, B. (2010). Dimensions of a projection column and architecture of VPM and POm axons in rat vibrissal cortex. Cereb. Cortex 20, 2265-2276. doi: 10.1093/cercor/bhq068

Wise, S. P., and Jones, E. G. (1977). Cells of origin and terminal distribution of descending projections of the rat somatic sensory cortex. J. Comp. Neurol. 175, 129-157. doi: 10.1002/cne.901750202

Womelsdorf, T., Valiante, T. A., Sahin, N. T., Miller, K. J., and Tiesinga, P. (2014). Dynamic circuit motifs underlying rhythmic gain control, gating and integration. Nat. Neurosci. 17, 1031-1039. doi: 10.1038/nn.3764

Woodruff, A. R., Anderson, S. A., and Yuste, R. (2010). The enigmatic function of chandelier cells. Front. Neurosci. 4:201. doi: 10.3389/fnins.2010.00201

Woodruff, A. R., McGarry, L. M., Vogels, T. P., Inan, M., Anderson, S. A., and Yuste, R. (2011). State-dependent function of neocortical chandelier cells. J. Neurosci. 31, 17872-17886. doi: 10.1523/jneurosci.3894-11.2011

Xiang, Z. (1998). Cholinergic switching within neocortical inhibitory networks. Science 281, 985-988. doi: 10.1126/science.281.5379.985

Xiang, Z., Huguenard, J. R., and Prince, D. A. (2002). Synaptic inhibition of pyramidal cells evoked by different interneuronal subtypes in layer $\mathrm{v}$ of rat visual cortex. J. Neurophysiol. 88, 740-750. doi: 10.1152/jn.00635.2001

$\mathrm{Xu}, \mathrm{X}$., and Callaway, E. M. (2009). Laminar specificity of functional input to distinct types of inhibitory cortical neurons. J. Neurosci. 29, 70-85. doi: 10 1523/JNEUROSCI.4104-08.2009

Xu, N., Harnett, M. T., Williams, S. R., Huber, D., O’Connor, D. H., Svoboda, K., et al. (2012). Nonlinear dendritic integration of sensory and motor input during an active sensing task. Nature 492, 247-251. doi: 10.1038/nature11601

Xu, H., Jeong, H. Y., Tremblay, R., and Rudy, B. (2013). Neocortical somatostatinexpressing gabaergic interneurons disinhibit the thalamorecipient layer 4 . Neuron 77, 155-167. doi: 10.1016/j.neuron.2012.11.004

Xu, X., Roby, K. D., and Callaway, E. M. (2010). Immunochemical characterization of inhibitory mouse cortical neurons: three chemically distinct classes of inhibitory cells. J. Comp. Neurol. 518, 389-404. doi: 10.1002/cne.22229

Xue, M., Atallah, B. V., and Scanziani, M. (2014). Equalizing excitationinhibition ratios across visual cortical neurons. Nature 511, 596-600. doi: 10. 1038/nature13321

Yamawaki, N., and Shepherd, G. M. G. (2015). Synaptic circuit organization of motor corticothalamic neurons. J. Neurosci. 35, 2293-2307. doi: 10. 1523/jneurosci.4023-14.2015

Yang, H., Kwon, S. E., Severson, K. S., and O'Connor, D. H. (2016). Origins of choice-related activity in mouse somatosensory cortex. Nat. Neurosci. 19, 127-134. doi: 10.1038/nn.4183

Ye, Z., Mostajo-Radji, M. A., Brown, J. R., Rouaux, C., Tomassy, G. S., Hensch, T. K., et al. (2015). Instructing perisomatic inhibition by direct lineage reprogramming of neocortical projection neurons. Neuron 88, 475-483. doi: 10 . 1016/j.neuron.2015.10.006

Yoshimura, Y., and Callaway, E. M. (2005). Fine-scale specificity of cortical networks depends on inhibitory cell type and connectivity. Nat. Neurosci. 8, 1552-1559. doi: 10.1038/nn1565

Yoshimura, Y., Dantzker, J., and Callaway, E. (2005). Excitatory cortical neurons form fine-scale functional networks. Nature 433, 868-873. doi: 10 . 1038/nature03252

Zagha, E., Casale, A. E., Sachdev, R. N. S., McGinley, M. J., and McCormick, D. A. (2013). Motor cortex feedback influences sensory processing by modulating network state. Neuron 79, 567-578. doi: 10.1016/j.neuron.2013. 06.008 
Zarrinpar, A., and Callaway, E. M. (2016). Functional local input to layer 5 pyramidal neurons in the rat visual cortex. Cereb. Cortex 26, 991-1003. doi: 10. 1093/cercor/bhu268

Zeisel, A., Muñoz-Manchado, A. B., Codeluppi, S., Lönnerberg, P., La Manno, G., Juréus, A., et al. (2015). Cell types in the mouse cortex and hippocampus revealed by single-cell RNA-seq. Science 347, 1138-1142. doi: 10.1126/science. aaa1934

Zhang, S., Xu, M., Kamigaki, T., Hoang Do, J. P., Chang, W.-C., Jenvay, S., et al. (2014). Long-range and local circuits for top-down modulation of visual cortex processing. Science 345, 660-665. doi: 10.1126/science. 1254126
Conflict of Interest Statement: The authors declare that the research was conducted in the absence of any commercial or financial relationships that could be construed as a potential conflict of interest.

Copyright (c) 2016 Naka and Adesnik. This is an open-access article distributed under the terms of the Creative Commons Attribution License (CC BY). The use, distribution and reproduction in other forums is permitted, provided the original author(s) or licensor are credited and that the original publication in this journal is cited, in accordance with accepted academic practice. No use, distribution or reproduction is permitted which does not comply with these terms. 